\title{
The BAR Domain Protein PICK1 Controls Vesicle Number and Size in Adrenal Chromaffin Cells
}

\author{
Paulo S. Pinheiro, ${ }^{1,2}$ Anna M. Jansen, ${ }^{1 \star}$ Heidi de Wit, ${ }^{3 \star}$ Bassam Tawfik, ${ }^{1,2}{ }^{\circledR}$ Kenneth L. Madsen, ${ }^{1}$ Matthijs Verhage, ${ }^{3}$ \\ Ulrik Gether, ${ }^{1,2}$ and Jakob B. Sørensen ${ }^{1,2}$ \\ ${ }^{1}$ Department of Neuroscience and Pharmacology, Faculty of Health and Medical Sciences and ${ }^{2}$ Lundbeck Foundation Center for Biomembranes in \\ Nanomedicine, University of Copenhagen, 2200N Copenhagen, Denmark, and ${ }^{3}$ Center for Neurogenomics and Cognitive Research, Department of \\ Functional Genomics, Vrije Universiteit Amsterdam and VU Medical Center, 1081 HV Amsterdam, The Netherlands
}

Protein Interacting with C Kinase 1 (PICK1) is a Bin/Amphiphysin/Rvs (BAR) domain protein involved in AMPA receptor trafficking. Here, we identify a selective role for PICK1 in the biogenesis of large, dense core vesicles (LDCVs) in mouse chromaffin cells. PICK1 colocalized with syntaxin-6, a marker for immature granules. In chromaffin cells isolated from a PICK1 knockout (K0) mouse the amount of exocytosis was reduced, while release kinetics and $\mathrm{Ca}^{2+}$ sensitivity were unaffected. Vesicle-fusion events had a reduced frequency and released lower amounts of transmitter per vesicle (i.e., reduced quantal size). This was paralleled by a reduction in the mean single-vesicle capacitance, estimated by averaging time-locked capacitance traces. EM confirmed that LDCVs were fewer and of markedly reduced size in the PICK1 K0, demonstrating that all phenotypes can be explained by reductions in vesicle number and size, whereas the fusion competence of generated vesicles was unaffected by the absence of PICK1. Viral rescue experiments demonstrated that long-term re-expression of PICK1 is necessary to restore normal vesicular content and secretion, while short-term overexpression is ineffective, consistent with an upstream role for PICK1. Disrupting lipid binding of the BAR domain (2K-E mutation) or of the PDZ domain (CC-GG mutation) was sufficient to reproduce the secretion phenotype of the null mutant. The same mutations are known to eliminate PICK1 function in receptor trafficking, indicating that the multiple functions of PICK1 involve a conserved mechanism. Summarized, our findings demonstrate that PICK1 functions in vesicle biogenesis and is necessary to maintain normal vesicle numbers and size.

Key words: adrenal chromaffin cells; amperometry; BAR domain; exocytosis; PICK1; vesicle biogenesis

\section{Introduction}

Adrenal chromaffin cells secrete catecholamines and various peptides, including chromogranins, into the blood stream as part of the "breed and feed" and the "fight or flight" response (Fulop et al., 2005). The final steps leading to exocytosis of large, dense core vesicles (LDCVs) have been intensively studied, and the main molecular players linking $\mathrm{Ca}^{2+}$ entry to vesicle fusion identified (Burgoyne and Morgan, 2003; Kasai et al., 2012). However, the proper biogenesis of LDCVs, which is fundamental to ensure that vesicles of the correct size, cargo filling, and membrane protein content are supplied for subsequent release, is less well un-

Received Dec. 9, 2013; revised June 16, 2014; accepted July 2, 2014.

Author contributions: P.S.P., K.L.M., M.V., U.G., and J.B.S. designed research; P.S.P., A.M.J., H.d.W., and B.T. performed research; P.S.P., A.M.J., H.d.W., B.T., and K.L.M. analyzed data; P.S.P. and J.B.S. wrote the paper.

This work was supported by the Lundbeck Foundation Center for Biomembranes in Nanomedicine (J.B.S. and U.G.); the Novo Nordisk Foundation (J.S.B. and U.G.); the Danish Medical Research Council (J.B.S. and U.G.); the Lundbeck Foundation (J.B.S. and P.S.P.); the Netherlands Organization for Scientific Research (MEERVOUD836.10.002 to H.d.W.); and the European Union Seventh Framework Programme under grant agreements FP7People-ITN-2008-238055 ("BrainTrain"; H.d.W. and M.V.), FP7-People- 2009-IEF-254647 ("Exosyts"; P.S.P.), and HEALTH-F2-2009-242167 ("SynSys"; J.B.S. and M.V.). We thank A.M.N. Petersen for excellent technical assistance.

*A.M.J. and H.d.W. contributed equally to this work.

The authors declare no competing financial interests.

Correspondence should be addressed to Jakob B. Sørensen, University of Copenhagen, Department of Neuroscience and Pharmacology, Faculty of Health Sciences, 1165 Copenhagen, Denmark. E-mail: jakobbs@sund.ku.dk.

DOI:10.1523/JNEUROSCI.5132-13.2014

Copyright $\odot 2014$ the authors $\quad 0270-6474 / 14 / 3410688-13 \$ 15.00 / 0$ derstood (Tooze et al., 2001; Borgonovo et al., 2006; Kim et al., 2006).

Bin/Amphiphysin/Rvs (BAR) domains are crescent-shaped, dimeric $\alpha$-helical modules that are capable of sensing, inducing, and/or stabilizing membrane curvature (Peter et al., 2004; Frost et al., 2009; Bhatia et al., 2010; Madsen et al., 2010; Suetsugu et al., 2010). The diversity of their mechanical function is best understood in relation to clathrin-mediated endocytosis, which involves at least four different BAR domain proteins, including FCHo1/2, endophilin, amphiphysin, and SNX9, each serving distinct roles in different steps of the budding and fission process (McMahon and Boucrot, 2011; Rao and Haucke, 2011; Saheki and De Camilli, 2012).

Protein interacting with C Kinase 1 (PICK1), islet cell antigen $69 \mathrm{kDa}$ (ICA69), and arfaptin-1/2 constitute a subfamily of BAR domain proteins that is conserved from Caenorhabditis elegans to humans (Staudinger et al., 1995; Habermann, 2004). Arfaptin-1 interacts with ADP-ribosylation factors (ARFs; Kanoh et al., 1997; Shin and Exton, 2001), which have been implicated in vesicle budding (Kirchhausen, 2000; Spang, 2008). The absence of arfaptin-1 in insulin-producing cells impairs formation of insulin-containing, dense core vesicles and it was proposed that arfaptin might be important for shielding the vesicle neck to prevent premature fission (Gehart et al., 2012). ICA69 was originally identified as a diabetes-associated auto-antigen in islet cells 
(Pietropaolo et al., 1993) and, interestingly, the C. elegans ortholog of ICA69, RIC-19, has been implicated in the maturation of neuronal LDCVs (Sumakovic et al., 2009; Hannemann et al., 2012).

The cellular functions of PICK1 have been extensively studied in the context of trafficking of AMPA receptors during certain forms of synaptic plasticity, where the PICK1 PDZ domain plays an important role ( $\mathrm{Lu}$ and Ziff, 2005; Jin et al., 2006; Steinberg et al., 2006; Hanley, 2008; Thorsen et al., 2010). PICK1 has recently been implicated in the formation and trafficking/maturation of secretory vesicles (Cao et al., 2013; Holst et al., 2013). However, it is still unclear whether PICK1 is exclusively involved in vesicle biogenesis, or whether it might also serve downstream roles once vesicles have formed. Here, we identified a function for PICK1 in maintaining the correct size and number of LDCVs in mouse chromaffin cells, making it a key player in the adrenergic system. Careful analysis of secretion and ultrastructure further indicate that formed vesicles retain full fusogenicity in the absence of PICK1, arguing against a downstream role of PICK1 in vesicle fusion itself.

\section{Materials and Methods}

Mouse line and chromaffin cell culture. We used the PICK1 KO mouse line generated previously by homologous recombination (Gardner et al., 2005; Steinberg et al., 2006). The mouse line was kept in the heterozygous condition and heterozygote crossings were used to create homozygous KO and WT littermates. Littermate WT animals were used as controls, unless noted otherwise in the text.

Chromaffin cells were isolated and cultured according to previously published protocols (Sørensen et al., 2003b). Adrenal glands from P0-P1 pups of either sex were dissected out, placed in filtered Locke's solution (154 mM NaCl, $5.6 \mathrm{~mm} \mathrm{KCl}, 0.85 \mathrm{~mm} \mathrm{NaH}_{2} \mathrm{PO}_{4}, 2.15 \mathrm{mM} \mathrm{Na}_{2} \mathrm{HPO}_{4}$, and $10 \mathrm{~mm}$ glucose, $\mathrm{pH} 7.0$ ), and cleaned. The glands were digested in $0.3 \mathrm{ml}$ of papain solution (see below) at $37^{\circ} \mathrm{C}$ for $40 \mathrm{~min}$ followed by the addition of $0.3 \mathrm{ml}$ of inactivating solution for 5-10 min. This solution was then replaced by $160 \mu \mathrm{l}$ of enriched DMEM, and the glands triturated through a $200 \mu$ l pipette tip. Fifty microliters of the cell suspension was plated as a drop on glass coverslips in 6-well plates, and the cells were allowed to settle for 20-40 min before adding $2 \mathrm{ml}$ of enriched DMEM. The cells were incubated at $37^{\circ} \mathrm{C}$ and $8 \% \mathrm{CO}_{2}$ and used within $4 \mathrm{~d}$. Papain solution consisted of DMEM (Gibco) supplemented with $0.2 \mathrm{mg} / \mathrm{ml}$ L-cysteine, $1 \mathrm{~mm} \mathrm{CaCl}, 0.5 \mathrm{~mm}$ EDTA, and $20-25 \mathrm{U} / \mathrm{ml}$ papain (Worthington Biochemical) and equilibrated with $8 \% \mathrm{CO}_{2}$. Inactivating solution consisted of DMEM supplemented with $10 \%$ heat-inactivated FCS (Invitrogen), $2.5 \mathrm{mg} / \mathrm{ml}$ albumin, and $2.5 \mathrm{mg} / \mathrm{ml}$ trypsin inhibitor (Sigma-Aldrich). Enriched DMEM consisted of DMEM supplemented with $4 \mu \mathrm{l} / \mathrm{ml}$ penicillin/streptomycin (Invitrogen) and $10 \mu \mathrm{l} / \mathrm{ml}$ insulintransferrin-selenium-X (Invitrogen).

Generation of viral vectors. For short-term re-expression experiments full-length PICK1 was cloned into a Semliki Forest Virus expression vector (pSFV1) containing an IRES followed by EGFP, to allow for the simultaneous, but independent, expression of both proteins. After PCR amplification PICK1 was inserted into the pSFV1 vector using BamHI and BssHII restriction sites upstream of the IRES. For long-term reexpression experiments, full-length PICK1 and PICK1 containing mutations that impair lipid binding of the BAR domain (K266E/K268E) or of the PDZ domain (C44G/C46G) were amplified by PCR and cloned into a pLVX-IRES-ZsGreen1 lentiviral (LV) vector (Clontech) using BamHI and EcoRI restriction sites. All constructs were verified by sequencing. The generation of LV and SFV particles followed standard protocols.

Exocytosis measurements. Combined capacitance measurements and amperometric recordings were performed essentially as described previously (Pinheiro et al., 2013). Capacitance measurements were performed by using the Lindau-Neher technique implemented as the "sine $+\mathrm{dc}$ " mode of the software lock-in extension of Pulse (HEKA), which allows long-duration capacitance measurements in a single sweep. A $1000 \mathrm{~Hz}$, $70 \mathrm{mV}$ peak-to-peak sinusoid voltage stimulus was superimposed onto a

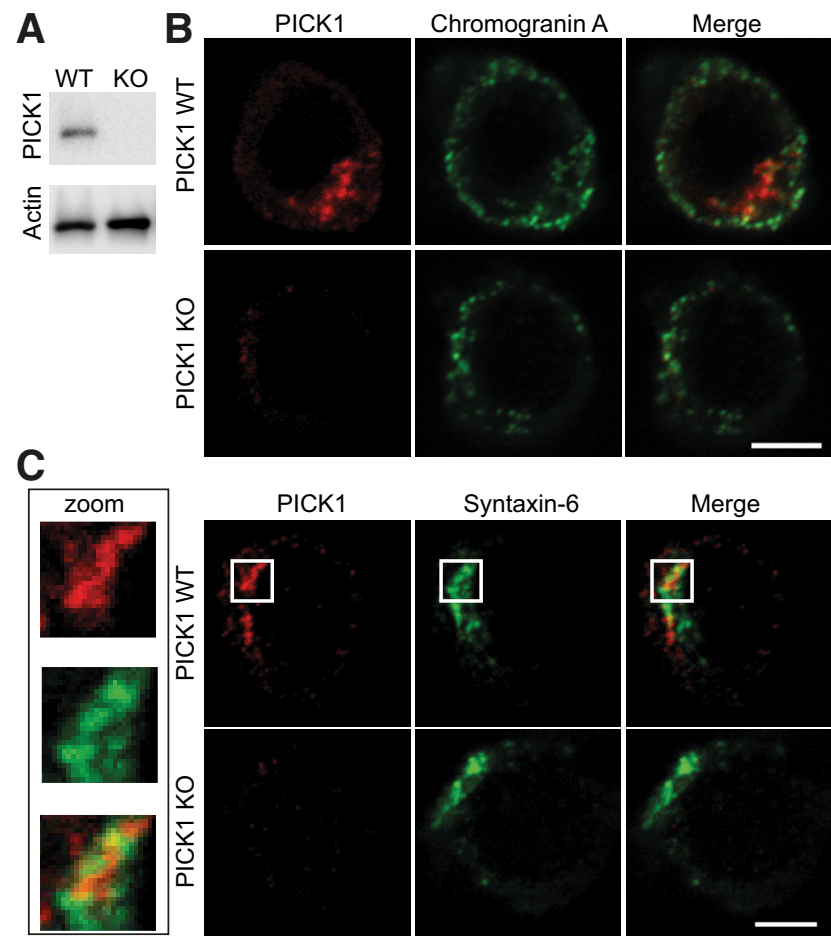

Figure 1. PICK1 is present in mouse chromaffin cells and partly colocalizes with syntaxin-6. $A$, Western blot analysis of whole adrenal glands verified expression of PICK1 in the WT and its elimination in the KO mice. Actin was used as a loading control. $\boldsymbol{B}$, Immunostaining for both PICK1 (red channel) and CgA (green channel) in chromaffin cells from WT (top row) and PICK1 KO (bottom row) mice. PICK1 localized to a perinuclear region, reminiscent of the TGN, but was absent from CgA-positive secretory granules. C, Immunostaining for both PICK1 (red channel) and syntaxin-6 (green channel) in chromaffin cells from WT (top row) and PICK1 KO (bottom row) mice. PICK1 partially colocalized with syntaxin-6, suggesting its presence on immature vesicles budding from the TGN. Scale bars: $\boldsymbol{B}, \boldsymbol{C}, 5 \mu \mathrm{m}$.

DC holding potential of $-70 \mathrm{mV}$. Currents were filtered at $3 \mathrm{kHz}$ and sampled at $12 \mathrm{kHz}$ using Pulse software. The release of catecholamines was triggered either by UV flash photolysis of a caged-calcium compound, nitrophenyl-EGTA, which was infused into the cell via the patch pipette, or by membrane depolarization.

Intracellular calcium concentrations were determined using two fluorescent dyes with different $\mathrm{Ca}^{2+}$ affinities (fura-4F and furaptra; Invitrogen; Voets, 2000; Sørensen et al., 2002) which, after calibration, allow calcium concentration measurements over a large dynamic range. For the ratiometric determination of the calcium concentration the excitation light was alternated between 350 and $380 \mathrm{~nm}$. Emitted light was detected with a photodiode, the signal filtered at $3 \mathrm{kHz}$, and sampled at 12 $\mathrm{kHz}$ using Pulse software. The 350/380 signal ratio was calibrated by infusion of cells with eight different solutions of known calcium concentrations. The intracellular solution contained the following (in $\mathrm{mM}$ ): 100 Cs-glutamate, $8 \mathrm{NaCl}, 4 \mathrm{CaCl}_{2}$, 32 Cs-HEPES, $2 \mathrm{Mg}$-ATP, $0.3 \mathrm{GTP}, 5$ $\mathrm{NPE}, 0.4$ fura- $4 \mathrm{~F}, 0.4$ furaptra, and 1 vitamin $\mathrm{C}$ (to prevent flash-induced damage to fura dyes), pH 7.2 (osmolarity adjusted to $\sim 295 \mathrm{mOsm}$ ). The extracellular solution was composed of the following (in mM): $145 \mathrm{NaCl}$, $2.8 \mathrm{KCl}, 2 \mathrm{CaCl}_{2}, 1 \mathrm{MgCl}_{2}, 10 \mathrm{HEPES}$, and 11 glucose, $\mathrm{pH} 7.2$ (osmolarity adjusted to $\sim 305 \mathrm{mOsm}$ ). The basal (pre-flash) calcium was determined by averaging all measurements in the $20 \mathrm{~s}$ preceding the flash protocol and was adjusted, when required, by brief monochromator illumination rapidly alternating between 350 and $380 \mathrm{~nm}$, causing gradual photolysis of caged calcium.

Amperometric recordings were performed using carbon fibers with 5 $\mu \mathrm{m}$ in diameter (Thornel P-650/42; Cytec), insulated using the polyethylene method (Bruns, 2004). Fibers were clamped to $700 \mathrm{mV}$, and currents were filtered at $5 \mathrm{kHz}$ by an EPC-7 (HEKA). Currents were acquired at $25 \mathrm{kHz}$ and filtered off-line for analysis using a Gaussian filter with a cutoff set at $1 \mathrm{kHz}$. Filtering, spike detection, and analysis were per- 
formed using a custom-written macro (Mosharov and Sulzer, 2005) running under IGOR Pro (WaveMetrics).

Information about pool sizes and fusion rates was obtained by fitting the capacitance traces with a sum of three exponential functions using custom macros written in IGOR Pro software. Single-vesicle capacitance was estimated using time-locked signal averaging from simultaneous measurements of membrane capacitance and amperometric spikes (Moser and Neher, 1997), because fusion of individual chromaffin granules cannot be resolved in whole-cell measurements. The time at the peak of individual amperometric spikes was used to align $200 \mathrm{~ms}$ segments of the simultaneously recorded membrane capacitance signal for averaging. The resulting capacitance step was corrected for baseline shift due to ongoing secretion by fitting a linear equation to the segment before the step and subtracting the resulting line from the actual data.

Immunocytochemistry. Chromaffin cells used for immunocytochemistry were cultured for $2 \mathrm{~d}$ on coverslips coated with poly-D-lysine (Sigma). Cells were fixated in 4\% PFA for 10 min on ice and $10 \mathrm{~min}$ at room temperature, permeabilized, and blocked in blocking solution (PBS w/3\% BSA) containing $0.3 \%$ saponin for $30 \mathrm{~min}$. Cells were then incubated overnight at $4^{\circ} \mathrm{C}$ with primary antibodies diluted in blocking solution. Following extensive washing, cells were incubated with secondary antibodies for $30 \mathrm{~min}$ at room temperature and mounted on slides using ProLong antifade (Life Technologies). PICK1 was visualized using either a custom-made mouse monoclonal antibody $2 \mathrm{G} 10$ or a polyclonal chicken anti-

PICK1 (Novus Biologicals). Both antibodies were diluted 1:500. Syntaxin-6 was visualized using mouse monoclonal 3D10 (Abcam) diluted 1:1000. Primary antibodies against tyrosine hydroxylase (TH) and chromogranin A ( $\mathrm{CgA})$ were mouse monoclonal MAB318 (Millipore; used 1:2000) and rabbit polyclonal ab15160 (Abcam; used 1:1000), respectively. All secondary antibodies were from goat (anti-rabbit, antimouse, or anti-chicken) and conjugated to Alexa Fluor 488, Alexa Fluor 546, Alexa Fluor 568, or Alexa Fluor 647 (Life Technologies). The immunofluorescence was visualized using a Zeiss LSM 510 or LSM 710 inverted confocal laser-scanning microscope equipped with an oil-immersion NA $1.463 \times$ objective (Zeiss). For quantification of $\mathrm{CgA}$, anti-TH visualized with Alexa Fluor488-conjugated secondary antibody was used to identify chromaffin cells. The CgA staining was kept in the far-red channel to avoid bleed through. CgA quantification was done using ImageJ software on $Z$-stacks with a $0.5 \mu \mathrm{m}$ increment between slices. For quantification of CgA immunoreactivity ROIs were outlined on images of the TH immunoreactivity and these ROIs were subsequently used for measuring total signal intensity in the far-red channel after background subtraction. All microscope settings were kept the same during imaging of the CgA signal, and thresholding for subtraction of background was unchanged during CgA quantification.

Western blot. Mouse adrenal glands were collected at P1 and homogenized in RIPA lysis buffer (Sigma) containing $1 \mathrm{~mm}$ PMSF and Complete Protease Inhibitor Cocktail (Roche). The lysate was cleared by a $15 \mathrm{~min}$ centrifugation at $11,000 \times \mathrm{g}$ at $4^{\circ} \mathrm{C}$. COS-7 cells were seeded out in 6-well plates, 250,000 cells per well, $1 \mathrm{~d}$ before infection. After LV infection the cells were left to express for $48 \mathrm{~h}$, then lysed in lysis buffer, and cleared by centrifugation. Total protein in the lysates was determined by a BCA assay (Thermo Scientific). Proteins in the COS-7 cell and adrenal gland lysates were separated by SDS-PAGE and blotted onto PVDF membranes. An amount of lysate corresponding to half a gland or $8 \mu \mathrm{g}$ total

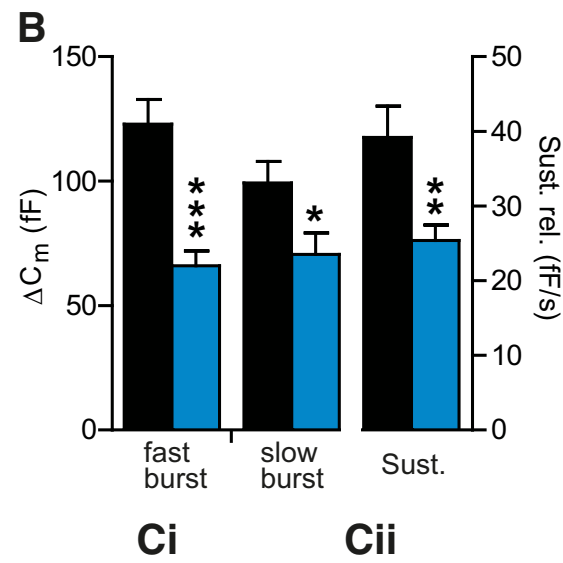

PICK1 WT
PICK1 KO
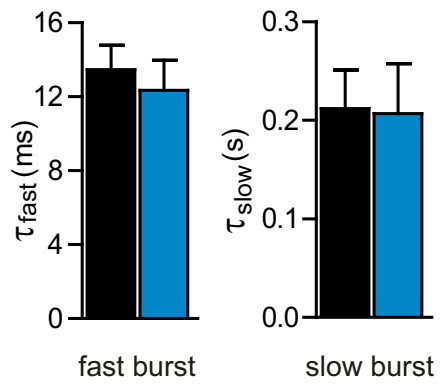

Figure 2. Genetic removal of PICK1 causes the reduction of secretory amplitude without affecting release kinetics. $\boldsymbol{A}$, Intracellular $\mathrm{Ca}^{2+}$ uncaging revealed reduced catecholamine release from PICK1 K0 chromaffin cells. Top, Mean \pm SEM intracellular concentration attained after UV photolysis of caged $\mathrm{Ca}^{2+}$ (red arrow). Middle, Averaged traces of the change in membrane (he overall rates of secretion (C). The sustained component (Sust.) was calculated as the slope of the capacitance trace between 1.5 and $5.5 \mathrm{~s}$. This component was also reduced in the absence of PICK1 (WT, $n=34$ cells; PICK1 K0, $n=29$ cells; ${ }^{*} p<$ $0.05,{ }^{* *} p<0.01$, and ${ }^{* * *} p<0.001$; Student's $t$ test).

protein for the COS-7 cells was loaded per well. Membranes were blocked in PBS with $0.1 \%$ Tween 20 and 5\% dry milk. The following primary antibodies were used, diluted in blocking solution: polyclonal rabbit anti-PICK1 (Abcam; 1:500), mouse monoclonal anti-PICK1 (Antibodies; 1:500), and polyclonal rabbit anti-CgA (Santa Cruz Biotechnology; $1: 1000)$. After incubation in primary antibody for $1 \mathrm{~h}$ at room temperature the blots were washed extensively and incubated in HRP-conjugated anti-mouse or anti-rabbit antibodies (Thermo Scientific; 1:10.000) and HRP-conjugated mouse monoclonal anti- $\beta$ actin antibody (Sigma; $1: 10.000$ ) in blocking solution for $30 \mathrm{~min}$. Following further washing the blots were developed using the ECL detection system (GE Healthcare) and imaged using a cooled CCD camera.

Electron microscopy of cultured chromaffin cells. Chromaffin cells from PICK1 KO mice and WT littermates $(\mathrm{P} 0-\mathrm{P} 1)$ were plated on coverslips coated with rat tail type 1 collagen (Cellocate; Eppendorf). After 2 DIV the cells were fixated for $45 \mathrm{~min}$ at room temperature with $2.5 \%$ glutaraldehyde in $0.1 \mathrm{M}$ cacodylate buffer, $\mathrm{pH}$ 7.4. After fixation cells were washed with cacodylate buffer, embedded, and analyzed as described before (Toonen et al., 2006). Analysis of secretory vesicle distribution was done blinded for the genotype of the animal. For each condition the distribution of secretory vesicles was analyzed in serial ultrathin sections $(\sim 90 \mathrm{~nm})$ of randomly selected chromaffin cells from different animals. Chromaffin cells were selected at low magnification in the JEOL 1010 electron microscope and subsequently examined at 20,000 $\times$ magnification. Only cells with a visible nucleus and clear-cut plasma membrane were taken into account. Secretory vesicles were recognized by their round, dense core. Docked vesicles were without any measurable distance between granule and plasma membrane. Distances from the granule membrane to the plasma membrane were measured on digital images acquired at 20,000 $\times$ magnification by a Kodak Megaplus $1.4 \mathrm{i}$ camera controlled by analySIS (Soft Imaging Systems/Olympus). For each con- 

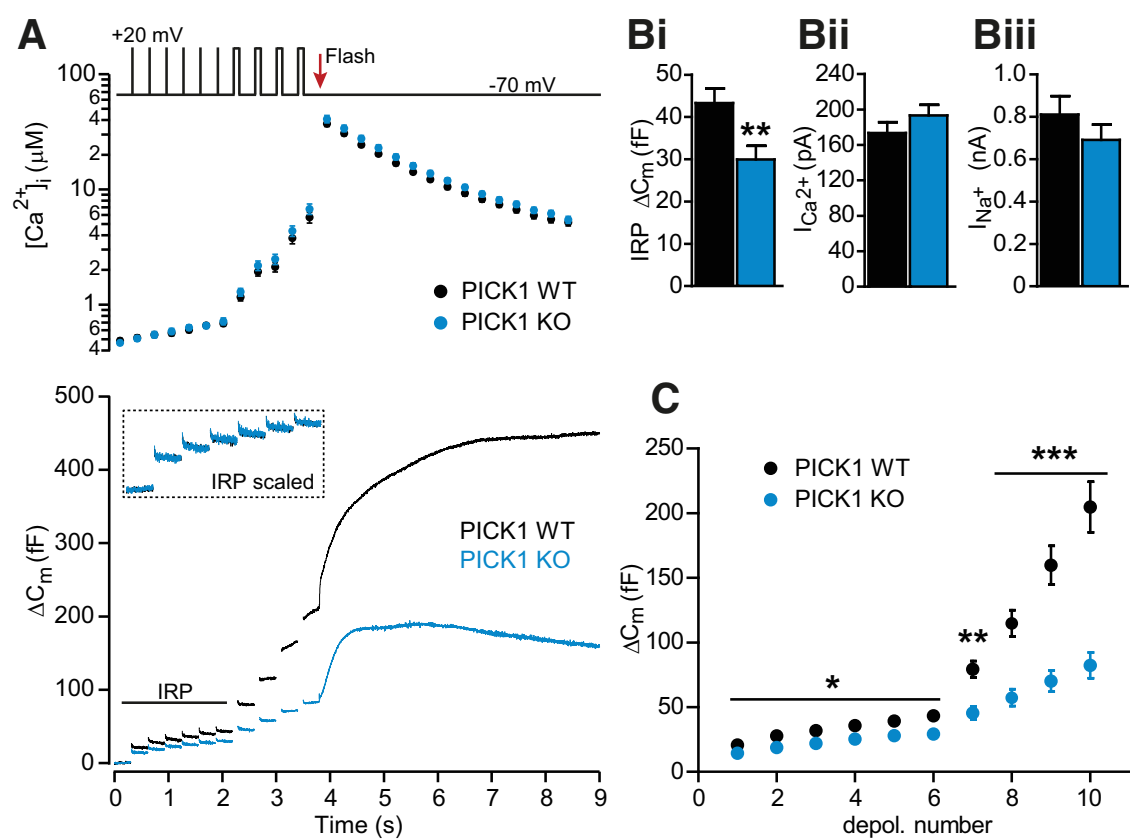

Figure 3. Secretory responses to membrane depolarizations are impaired in PICK1 K0 chromaffin cells. $A$, Successive membrane depolarizations to $+20 \mathrm{mV}$ ( 6 depolarizations of 10 ms duration and 4 depolarizations of 100 ms duration; Voets et al., 1999) were performed while monitoring intracellular $\left[\mathrm{Ca}^{2+}\right]$ (mean \pm SEM; top) and membrane capacitance (mean trace; bottom). A UV flash (red arrow) was applied to uncage $\mathrm{Ca}^{2+}$ after the last depolarization to monitor the pool of vesicles still available for release. Inset, Capacitance response to the first six depolarizations scaled to the same amplitude (IRP size) shows that the release probability upon the first depolarization was identical between the genotypes. Bi, The absence of PICK1 caused a significant reduction in the size of the IRP without changes in the amplitude of $\mathrm{Ca}^{2+}$ (Bii) or $\mathrm{Na}^{+}$(Biii) currents. C, A significantly reduced secretion in response to membrane depolarization was seen for all stimulations in the protocol. (WT $n=24$ cells; PICK1 KO $n=25$ cells; ${ }^{*} p<$ $0.05,{ }^{* *} p<0.01$, and ${ }^{* * *} p<0.001$; Student's $t$ test).

dition the relative frequency of docked vesicles was calculated, and cumulative distance histograms were created of the relative frequency of all vesicles according to the number of vesicles counted in this area. In addition, the total number of vesicles was counted and the diameter of secretory vesicles was analyzed.

Statistical analysis. Data are presented as mean \pm SEM with $n$ indicating the number of cells. Statistical comparisons were made using an unpaired, two-tailed Student's $t$ test, or one-way ANOVA, unless otherwise stated.

\section{Results}

Adrenal chromaffin cells release adrenaline, which is a major output of the sympathetic nervous system, together with various peptides. Catecholamine and peptide secretion occurs through the fusion of LDCVs with the plasma membrane using the same basic exocytotic machinery that operates in transmitter release in central neurons. Easily accessible and amenable to direct measurements of release by capacitance and amperometry measurements, chromaffin cells constitute a versatile assay system for fast, calcium-triggered exocytosis (Rettig and Neher, 2002).

\section{Genetic removal of PICK1 impairs catecholamine secretion}

To understand what role, if any, PICK1 plays in adrenal chromaffin cell physiology, we began by assessing whether it is expressed in these cells. Western blotting of adrenal gland extracts verified expression of PICK1, as well as its elimination in PICK1 KO animals (Fig. 1A). We next performed immunostaining for PICK1 as well as for either CgA, which localizes to LDCVs, or syntaxin-6, which localizes to immature vesicles at the transGolgi network (TGN; Klumperman et al., 1998; Wendler et al., 2001). We found that the PICK1 immunosignal was localized to a perinuclear compartment and appeared to be largely absent from mature secretory granules positive for $\mathrm{CgA}$, which are localized at the cell periphery (Fig. $1 B$ ). The remaining weak signal throughout the cell was also found in cells from PICK1 KO mice and was, therefore, unspecific (Fig. $1 B$, bottom). PICK1 was also found, at least partially, to colocalize with syntaxin6-positive compartments (Fig. 1C), in agreement with recent studies in growth hormone-secreting cells (Holst et al., 2013). Those studies also identified deficits in the levels of secreted hormones, but a detailed analysis of secretion using single-cell methods with high temporal resolution was not performed. Thus, it remains unknown whether deletion of PICK1 affects only vesicle biogenesis, or also downstream steps in the exocytotic cascade, including vesicle docking to the plasma membrane, priming to gain release competence, or fusion.

We examined catecholamine secretion from PICK1 KO chromaffin cells, and PICK1 WT littermates, using electrophysiological techniques. This was accomplished by monitoring membrane capacitance, which is proportional to cell membrane area and increases upon vesicle fusion. Simultaneously, we measured the secreted catecholamines by carbon fiber amperometry. This method detects the electrochemical current caused by electron transfer during transmitter oxidation on the fiber surface, and allows for singlevesicle fusion events to be resolved. Exocytosis was triggered by UV flash photolysis of caged $\mathrm{Ca}^{2+}$, which allows for a nearinstantaneous and uniform elevation of the $\left[\mathrm{Ca}^{2+}\right]_{i}$, which depletes the primed vesicle pools and reveals both the vesicle pool size and fusion kinetics. Furthermore, the basal (pre-flash) $\left[\mathrm{Ca}^{2+}\right]_{\mathrm{i}}$ was kept relatively high $(639 \pm 28 \mathrm{nM}, n=34$ for WT and $619 \pm 22 \mathrm{nM}, n=29$ for PICK1 KO) to build up a large releasable pool of vesicles by stimulating priming (Voets, 2000). In this experimental setting PICK1 KO cells displayed a marked reduction in secretion, as revealed by both membrane capacitance and amperometric measurements (Fig. $2 \mathrm{~A}$, middle and bottom). All phases of secretion, discriminated by fitting a sum of exponential components to the membrane capacitance traces, were significantly reduced (fast burst, $123 \pm 10 \mathrm{fF}, n=34$ for WT and $66 \pm$ $6 \mathrm{fF}, n=29$ for KO, $p<0.0001$; slow burst, $99 \pm 9 \mathrm{fF}, n=34$ for $\mathrm{WT}$ and $71 \pm 9 \mathrm{fF}, n=29$ for KO, $p=0.0226$; sustained, $39 \pm 4$ $\mathrm{fF} / \mathrm{s}, n=34$ for WT and $25 \pm 2 \mathrm{fF} / \mathrm{s}, n=29$ for $\mathrm{KO}, p=0.0048$; Fig. $2 B$ ). The fast burst of release originates from the readily releasable pool (RRP) of vesicles, whereas the slow burst of release is commonly assumed to originate from a slowly releasable pool (SRP). However, in a recent study we concluded that the SRP vesicles are most likely not fusogenic and need to mature to the RRP state before fusing (Walter et al., 2013). Our data show that both pools are decreased in size in the absence of PICK1. There were no changes in fusion kinetics of either the fast or slow bursts (Fig. 2Ci,Cii).

We also stimulated the cells using a membrane depolarization protocol designed to distinguish between the immediately releasable pool (IRP) of vesicles and the RRP (Fig. $3 A, B$ ). Six brief 
depolarizations ( $10 \mathrm{~ms}$ to $+20 \mathrm{mV}$ ) cause a spatially restricted increase in $\left[\mathrm{Ca}^{2+}\right]_{\mathrm{i}}$ and release the IRP vesicles, which are positioned close to calcium channels, and are followed by four longer depolarizations $(100 \mathrm{~ms}$ to $+20 \mathrm{mV})$ that cause global $\left[\mathrm{Ca}^{2+}\right]_{\mathrm{i}}$ elevation and release the entire RRP (Horrigan and Bookman, 1994; Voets et al., 1999). A calciumuncaging stimulus was applied to assess the remaining release capability of the cells. In the absence of PICK1 the exocytotic responses to membrane depolarizations were impaired, already from the first short stimulus (Fig. 3A, bottom, $C$ ). The IRP (integrated capacitance over the six brief depolarizations) was significantly reduced $(43.3 \pm 3.4 \mathrm{fF}, n=24$ for WT and $29.9 \pm 3.2$ $\mathrm{fF}, n=24$ for PICK1 KO, $p=0.0066$; Fig. $3 \mathrm{Bi}$ ) without changes to either calcium currents (Fig. 3Bii) or sodium currents (Fig. 3Biii). Normalizing the capacitance traces to the same IRP size showed that the release probability by a single depolarization was identical between WT and PICK1 KO cells (Fig. 3A, insert). Overall, these results demonstrate that, in PICK1 KO cells, the releasable pools of vesicles, including the IRP, $\mathrm{RRP}$, and SRP, are all reduced in size, but fuse with normal kinetics.

\section{Unchanged calcium dependence of} release in the absence of PICK1

PICK1 has been reported to bind calcium and to function as a calcium sensor for AMPA receptor trafficking induced by NMDA receptors (Hanley and Henley, 2005) and AMPA receptor intracellular retention during synaptic plasticity processes (Jo et al., 2008; Citri et al., 2010). We therefore asked whether PICK1 might exert a direct calcium-dependent role in chromaffin granule exocytosis. To examine the calcium dependence of fusion onset, we illuminated the cells by rapidly alternating monochromator illumination between 350 and $380 \mathrm{~nm}$; this causes slow calcium uncaging and allows for simultaneous capacitance and ratiometric calcium measurements (Sørensen et al., 2002). The resulting calcium "ramp" (Fig. $4 A, B$, top) elicits a sigmoid-shaped increase in membrane capacitance (Fig. $4 A, B$, red trace in middle; shown are two representative recordings). The secretion threshold was determined as the $\left[\mathrm{Ca}^{2+}\right]_{\mathrm{i}}$ at the first maximum of the second derivative of the capacitance trace, reflecting the maximal acceleration in release (Fig. $4 A, B$, bottom). The secretion threshold provides a sensitive measurement of the calcium dependence of release, which is altered by mutations in synaptotagmin-1 that change its $\mathrm{Ca}^{2+}$ affinity (Sørensen et al., 2003a), or when interfering with the ability of
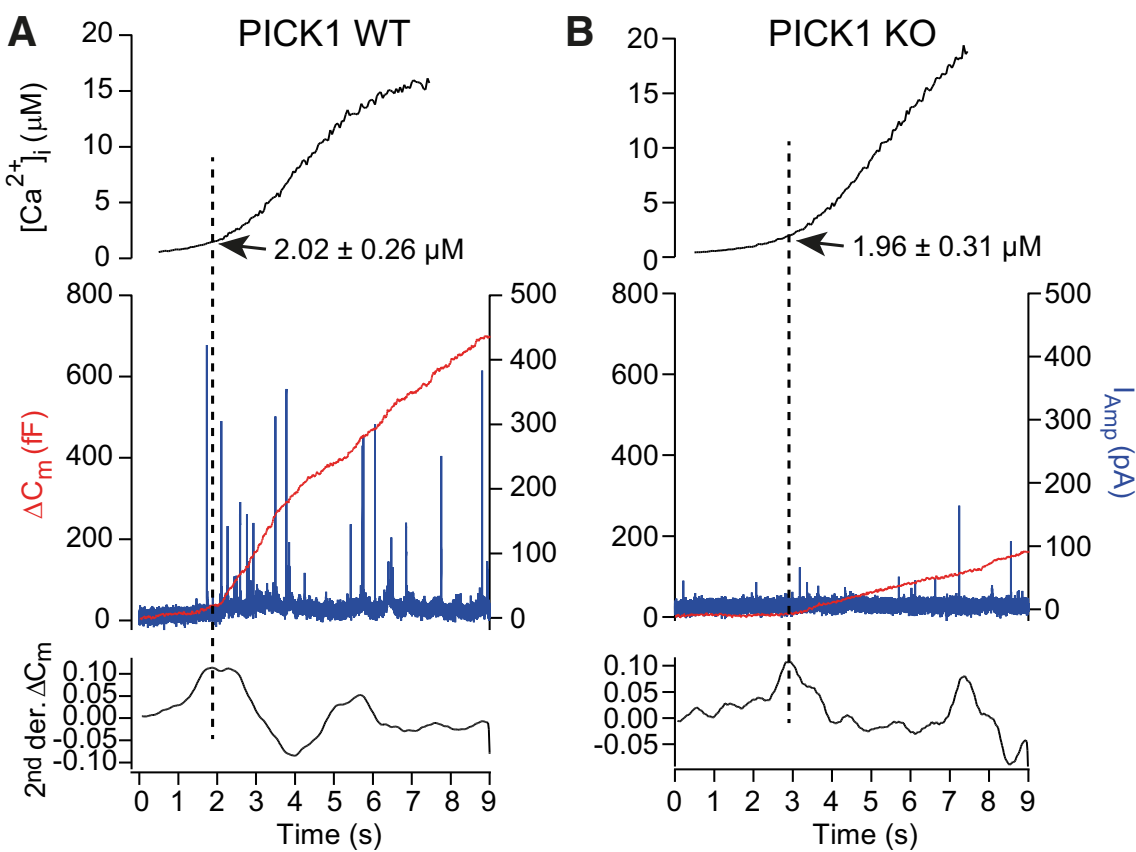

Figure 4. The $\mathrm{Ca}^{2+}$ dependence of secretion is unchanged in the absence of PICK1. Secretion was elicited by fast, intermittent and low intensity UV illumination to gradually release caged $\mathrm{Ca}^{2+}$ and increase the free $\left[\mathrm{Ca}^{2+}\right]_{\mathrm{i}}$ in a ramp-like manner. $A$, Example recording from a WT chromaffin cell. Top, Intracellular $\left[\mathrm{Ca}^{2+}\right]$ obtained by ratiometric fura dye measurements. Middle, Cell capacitance change (red trace, left axis) and amperometric current (blue trace, right axis) in a representative cell elicited by the gradual increase in intracellular $\mathrm{Ca}^{2+}$. Note the change in slope of the capacitance trace and the concomitant appearance of amperometric spikes, indicating the onset of secretion. Bottom, Plot of the second derivative of the $C_{m}$ trace over time, used to estimate the onset of secretion. $\boldsymbol{B}$, Similar experiment as depicted in $\boldsymbol{A}$ performed on a PICK1 K0 chromaffin cell (WT $n=18$ cells; KO $n=18$ cells).

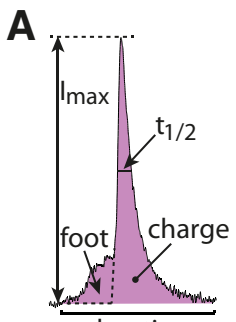

duration
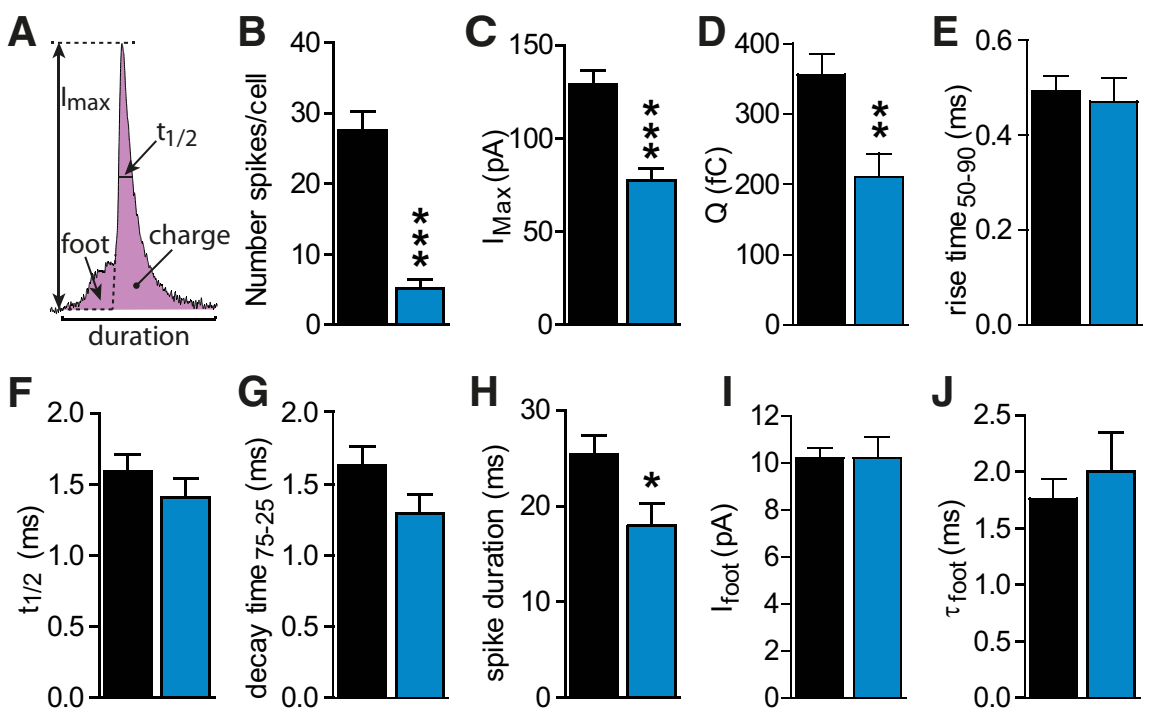

Figure 5. The quantal size is reduced in the absence of PICK1 without affecting fusion pore duration. $\boldsymbol{A}$, Depiction of the various parameters analyzed from each single amperometric spike, corresponding to the release of an individual LDCV. $\boldsymbol{B}$, The number of spikes per cell recorded (10 s duration) during a $\mathrm{Ca}^{2+}$ ramp was markedly lower in PICK1 K0 chromaffin cells. Both the maximum spike amplitude $(\boldsymbol{C})$ and amperometric charge $(\boldsymbol{D})$ were also significantly reduced in the absence of PICK1. The kinetics of single fusion events, such as rise time $(\boldsymbol{E})$, duration at half-maximal amplitude $(\boldsymbol{F})$, and decay time $(\boldsymbol{G})$, were not significantly altered, but there was an overall shorter event duration in recordings from PICK1 KO cells $(\boldsymbol{H})$. The stability of fusion pores was not altered, as shown by the unchanged foot amplitude $(\boldsymbol{I})$ and duration $(\boldsymbol{J})$. The amperometric data was obtained from the experiments depicted in Figure 4. (Black, WT, $n=18$ cells; blue, PICK1 K0 $n=18$ cells; ${ }^{*} p<0.05,{ }^{* *} p<0.01$, and ${ }^{* * *} p<0.001$; Student's $t$ test).

SNAP-25 to interact with synaptotagmin-1 (Mohrmann et al., 2013). We found that in PICK1 KO cells this threshold for secretion onset was unchanged (Fig. $4 A, B$ ), indicating that PICK1 does not affect the calcium dependence of LDCV fusion. 

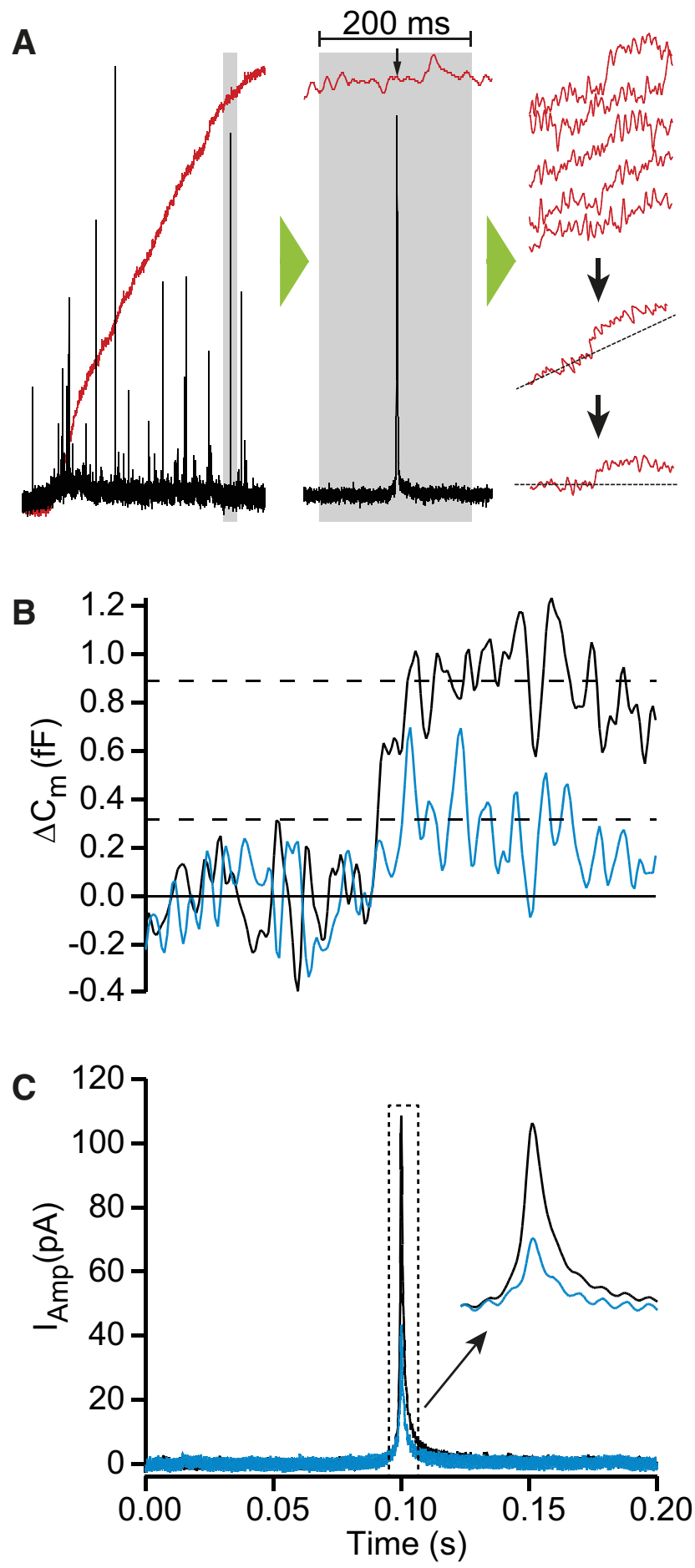

Figure 6. The single-vesicle capacitance is reduced in the absence of PICK1.A, Individual amperometric spikes recorded during calcium ramps (left) were automatically detected and cut out together with a $200 \mathrm{~ms}$ segment of the simultaneously recorded $C_{m}$ (middle). Hundreds of such time-locked capacitance traces (right top) were averaged, resulting in a resolvable single-step increase (right middle) on the background of a slope due to the ongoing fusion of vesicles not time-locked to the detected spike. Finally, subtraction of a linear slope isolates the step associated with a single-vesicle fusion event (right bottom). $\boldsymbol{B}$, Mean cell-capacitance change upon fusion of a single LDCV and ( $(\boldsymbol{)}$ the corresponding averaged singleamperometricspike, timelocked to the $C_{m}$ signal (blacktrace, WT; bluetrace, PICK1 KO). The mean single LDCV $C_{m}$ values were 0.94 and $0.31 \mathrm{ff}$ for WT and PICK1 KO, respectively.

Reduced single-vesicle transmitter release but unaltered fusion kinetics

In the experiments described previously, simultaneous amperometric recordings of released catecholamines were also per-
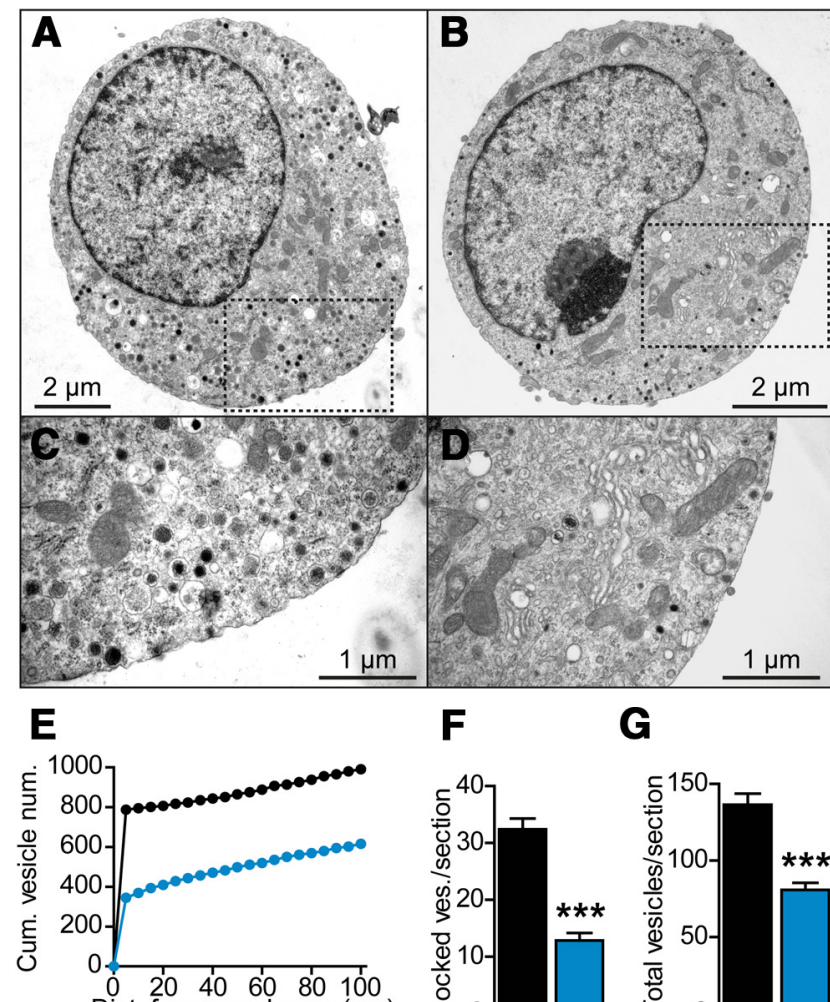

$\mathbf{F}$

G
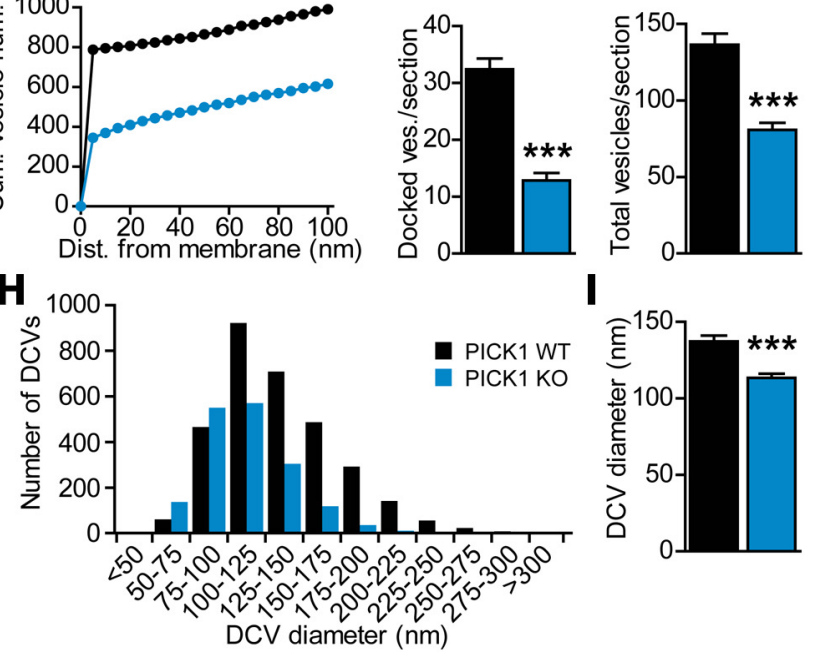

I

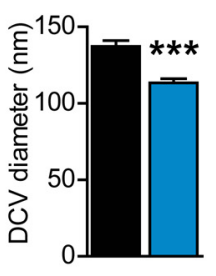

Figure 7. Reduced number and size of vesicles in PICK1 K0 chromaffin cells. $A, B$, Electron micrographs of a representative WT cell and a PICK1 KO cell. $C, D$, Insets of the dotted areas in $\boldsymbol{A}$ and $\boldsymbol{B}$ at higher resolution. $\boldsymbol{E}$, Cumulative vesicle distribution within the first $100 \mathrm{~nm}$ from the plasma membrane. $\boldsymbol{F}$, The number of docked LDCVs and $(\boldsymbol{G})$ the total number of LDCVs per section were significantly reduced in the absence of PICK1. $\boldsymbol{H}$, Histogram of the size distribution of LDCVs in electron micrographs from WT and PICK1 KO chromaffin cells, in $25 \mathrm{~nm}$ bins, shows markedly smaller vesicle size in PICK1 KO cells. I, Mean LDCV diameter (black, WT, $n=24$ cells from 5 mice; blue, PICK1 K0, $n=25$ cells from 5 mice; ${ }^{* * *} p<0.001$; Student's $t$ test).

formed (Fig. $4 A, B$, blue trace in middle), and revealed a quite striking phenotype; not only were there less single-fusion events in the PICK1 KO, but they appeared to be of much smaller amplitude. Thus, we performed a thorough analysis of single amperometric spike parameters (Fig. 5A; Mosharov, 2008). This revealed that, indeed, not only the number of detected events was significantly reduced in PICK1 KO cells (Fig. $5 B$ ), but also the amplitude (Fig. $5 C$ ) and charge (which is calculated as the time integral of the amperometric current and directly reflects the total amount of catecholamines oxidized at the electrode; Fig. $5 D$ ) were decreased to $\sim 59 \%$ of control cells. The kinetic features of single spikes were not changed (Fig. $5 E-G$ ), with exception of the total spike duration, which was shorter in the KO cells (Fig. $5 H$ ). However, this could be caused indirectly because a smaller spike will blend with the noise of the recording, resulting in an underestimation of the duration. Amperometric spikes are often 

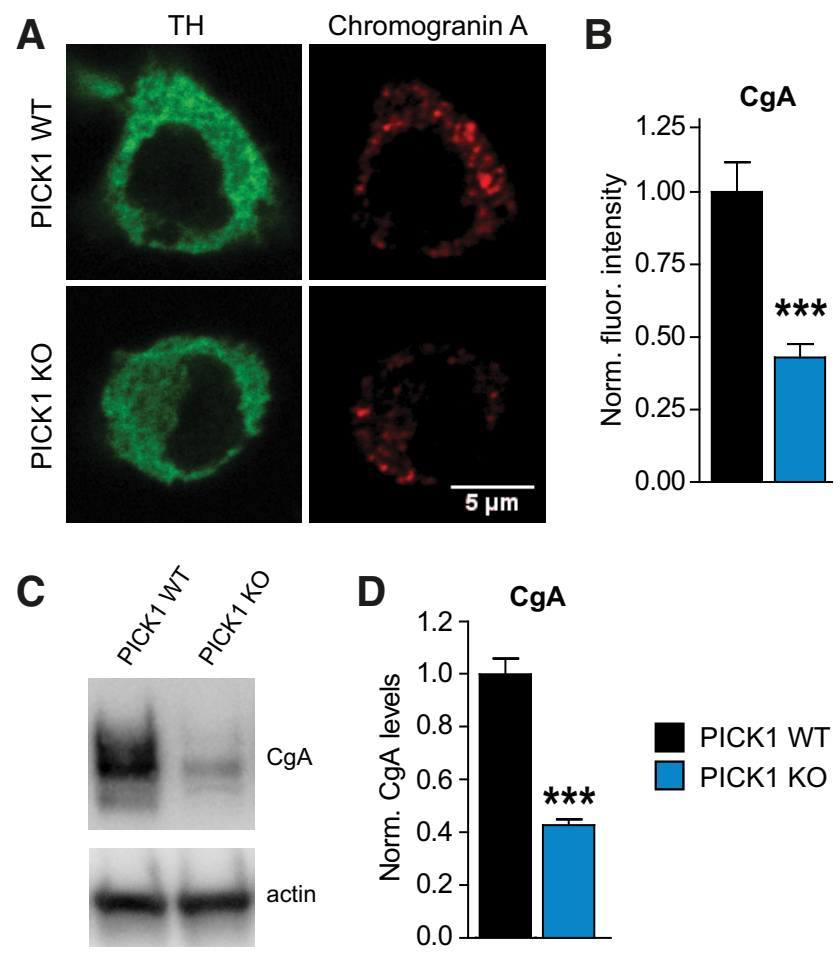

Figure 8. C C $\mathrm{A}$ is reduced in the absence of PICK1. A, Single confocal slices of chromaffin cells from both WT and PICK1 KO mice immunostained for TH (green channel) and ( $g A$ (red channel). The TH staining was used to allow the unbiased identification of chromaffin cells. $\boldsymbol{B}$, Normalized CgA fluorescent signal in WT (black; $n=51$ cells) and PICK1 K0 cells (blue; $n=53$ cells) obtained from the maximum intensity projection of a confocal stack through the entire cell. $C$, Western blot against CgA in single adrenal glands from PICK1 WT and K0 animals. D, Quantification of three Western blots from different animals. In the absence of PICK1 there was a marked reduction in the amount of $\mathrm{CgA}$ present in the adrenal glands and in individual chromaffin cells $\left({ }^{* *} p<0.0001\right.$; Student's $t$ test).

preceded by a so-called pre-spike foot that reflects transmitter leakage trough the forming fusion pore (Chow et al., 1992; Jackson and Chapman, 2008). The pre-spike foot parameters were indistinguishable between PICK1 KO and control cells (Fig. $5 I, J)$, further supporting the notion that PICK1 does not directly participate in LDCV fusion. These results show that less LDCVs fuse with the plasma membrane in PICK1 KO than in WT cells, but also suggest that those LDCVs are either smaller in size or pack smaller amounts of transmitter.

To distinguish between these two hypotheses we further analyzed the data depicted in Figure 4 to extract the mean singlevesicle capacitance, which is proportional to the vesicles' membrane area. Since the fusion of individual chromaffin granules cannot be resolved in whole-cell measurements, we used time-locked signal averaging from the simultaneous measurements of membrane capacitance and amperometric spikes (Moser and Neher, 1997). The time at peak of each amperometric spike was used to align and average $200 \mathrm{~ms}$ segments of the simultaneously recorded membrane capacitance (204 events for PICK1 KO and 609 events for WT). The resulting capacitance step, after correction of the sloping baseline (see Materials and Methods; Fig. 6A), represents the mean change in membrane capacitance upon fusion of a single LDCV (Fig. 6B). Single amperometric spikes were also averaged for comparison (Fig. 6C). This exercise revealed an estimate of the single-vesicle capacitance of $0.94 \mathrm{fF} /$ vesicle in WT cells, slightly less than the $1.3 \mathrm{fF}$ (Moser and Neher, 1997) and 1.25 fF (Tabares et al., 2001) re- ported previously for adult mouse and adult rat chromaffin cells, respectively. This is in line with the finding that chromaffin cells from newborn mice (used here; see size estimate below) have, on average, smaller vesicles than adult ones (Lipovšek et al., 2013). In PICK1 KO cells the single-vesicle capacitance was markedly reduced (to $0.31 \mathrm{fF} /$ vesicle), indicating that fusing LDCVs are smaller in the absence of PICK1.

\section{Reduced LDCV size and number in the absence of PICK1}

The reduced number of single-release events and their smaller charge, together with a smaller single-vesicle capacitance, all point to the presence of smaller and fewer vesicles. However, other scenarios are also possible; for example, the absence of PICK1 could lead to changes in LDCV formation or maturation that would cause small vesicles to fuse preferentially, without altering their number or cellular distribution. To clarify this we performed EM in PICK1 KO cells, in parallel with littermate controls, and quantified LDCV number, size, and cellular distribution (Fig. 7). The EM revealed normal cell morphology (Fig. $7 A, B$ and higher magnification insets in $C, D)$. However, there was a clear change in the number of vesicles in the cell (Fig. $7 E, G)$, with a reduction in both the number of vesicles docked to the plasma membrane $(32 \pm 2, n=23$ for WT and $13 \pm 1, n=25$ for PICK1 KO; $p<0.0001$; Fig. $7 F)$ and the total number of vesicles per EM section ( $136 \pm 7, n=23$ for WT and $81 \pm 5, n=$ 25 for PICK1 KO; $p<0.0001$; Fig. $7 G)$. There was also a clear shift in the distribution of LDCVs size (Fig. $7 \mathrm{H}$ ), and the mean vesicle diameter was significantly smaller in the absence of PICK1 $(137.2 \pm 3.9 \mathrm{~nm}, n=23$ cells for WT and $113.3 \pm 2.8 \mathrm{~nm}, n=25$ cells for PICK1 KO; $p<0.0001$; Fig. 7I). With these data, we repeated the CgA staining in PICK1 KO and WT cells, now using simultaneous staining against $\mathrm{TH}$ to identify chromaffin cells independently of their CgA or PICK1 staining. These stainings confirmed that the levels of $\mathrm{CgA}$ were significantly reduced in the PICK1 KO chromaffin cells (Fig. 8A,B). A similar reduction in the PICK1 KO was found by immunoblotting protein extracts obtained from individual adrenal glands (Fig. $8 C, D$ ).

Remarkably, the LDCV volume in PICK1 KO cells, estimated from the vesicle diameter obtained in the EM micrographs, is expected to be $56 \%$ of the WT LDCV volume, which aligns well with the reduction of quantal content to $59 \%$, as detected by amperometry (see above). This suggests no defect in transmitter filling in the PICK1 KO. The reduction in single-vesicle capacitance in the PICK1 KO, as estimated by electrophysiology, is larger than expected from EM, which is probably due to the very noisy nature of the single-vesicle capacitance signal (Fig. 6B). We conclude that the EM analysis establishes the presence of smaller and fewer LDCVs in PICK1 KO cells.

\section{Normal secretion can be restored by long-term but not short-} term PICK1 re-expression

The secretion deficit and the changes in vesicle number and size observed in PICK1 KO cells are quite profound and could be associated with developmental shortfalls indirectly linked to the loss of PICK1. We, therefore, sought to rescue the null phenotype by re-expressing the full-length PICK1 protein in dissociated chromaffin cells using an SFV; it expressed PICK1 followed by an IRES and EGFP as an expression marker. The cells were infected for $6-7 \mathrm{~h}$ and then analyzed for a possible rescue of secretion, using the calcium uncaging protocol (Fig. 2), by direct comparison with uninfected PICK1 KO cells and littermate WT cells. This, however, led to a failure in rescuing the secretion deficit seen in PICK1 KO cells (Fig. 9A-C). We, nevertheless, found the 

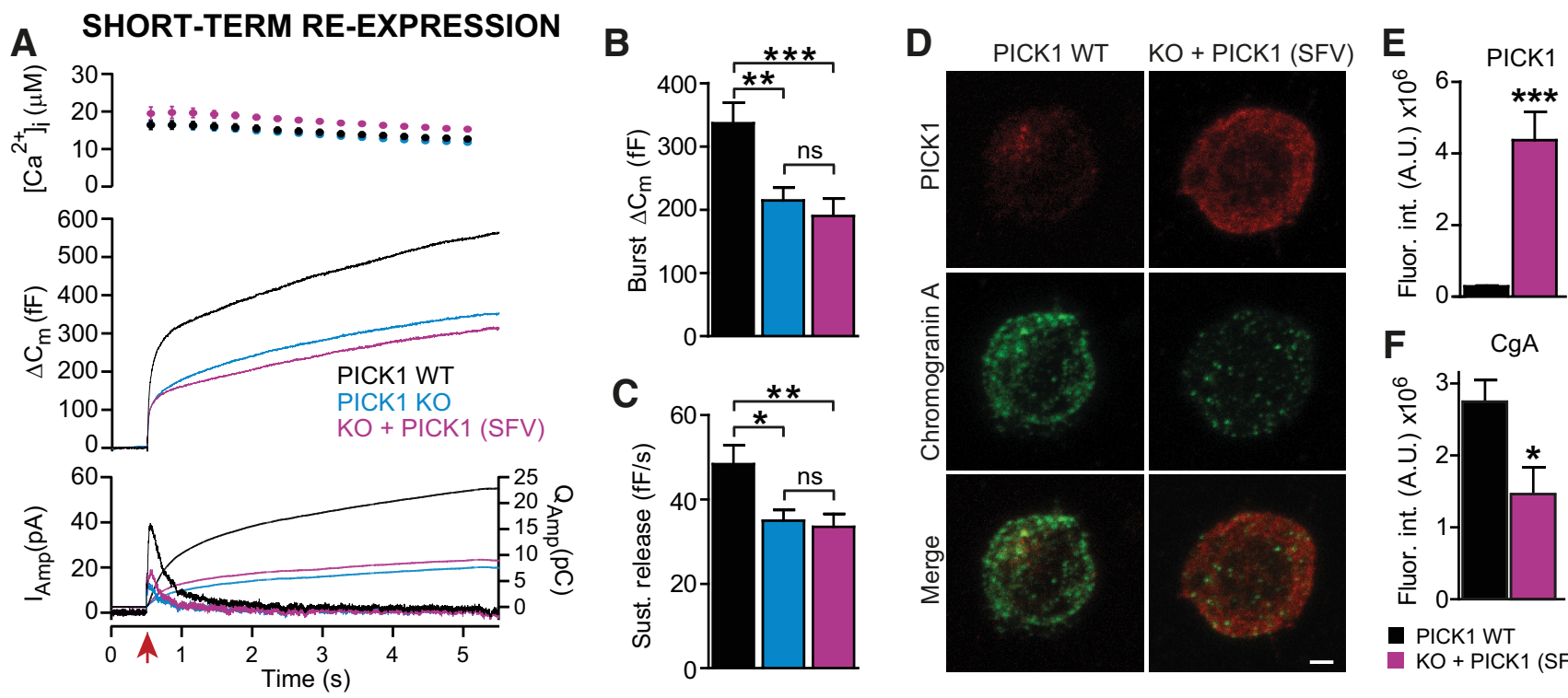

- PICK1 WT

KO + PICK1 (SFV)

\section{G LONG-TERM RE-EXPRESSION}
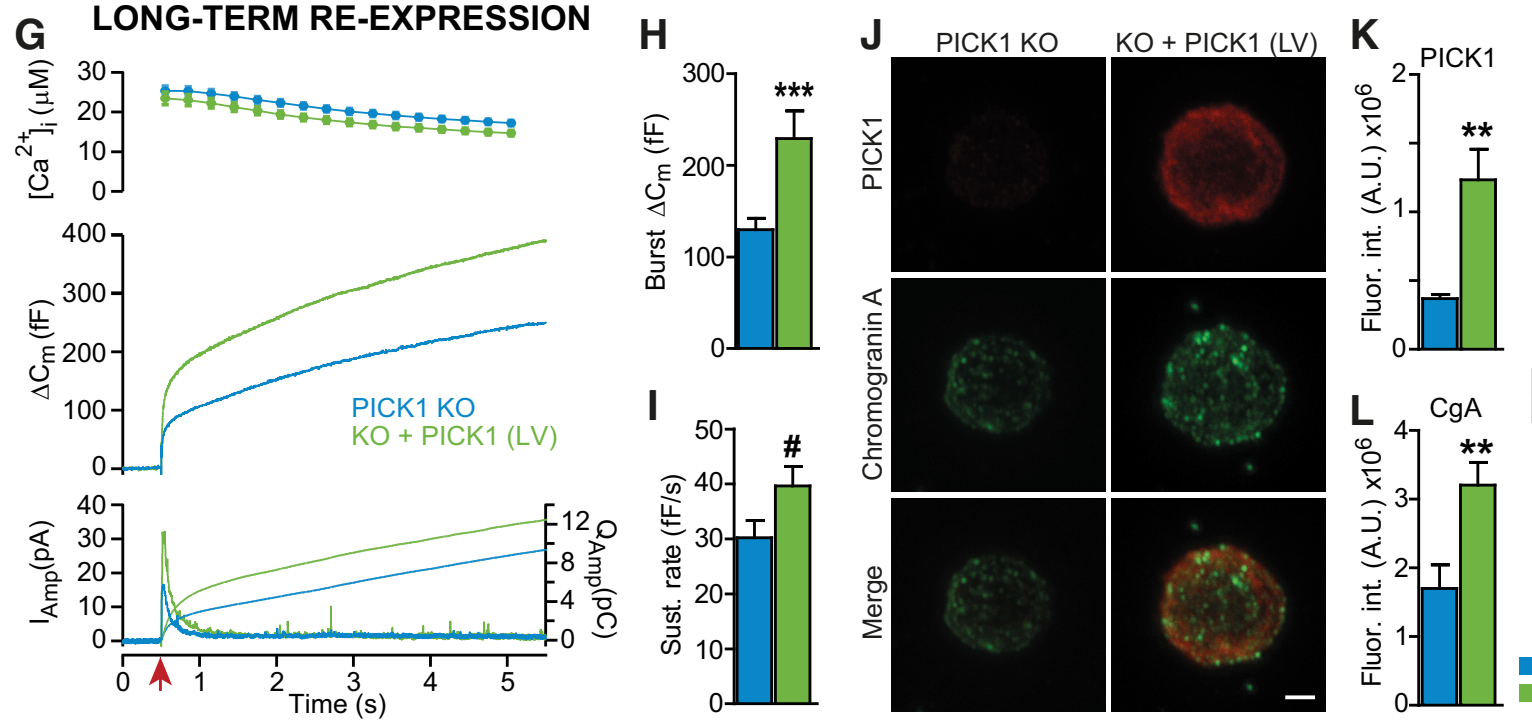

M

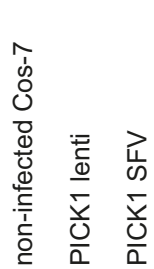

PICK1 KO

KO + PICK1 (LV)

Figure 9. Long-term re-expression of PICK1 is required to rescue the secretion deficit. $\boldsymbol{A}-\boldsymbol{F}$, Short-term PICK1 re-expression using a SFV vector. $\boldsymbol{A}$, Top, Mean \pm SEM intracellular $\left[C^{2+}{ }^{2+}\right]$ attained after UV photolysis of caged $\mathrm{Ca}^{2+}$. Middle, Averaged traces of membrane capacitance change upon $\mathrm{Ca}^{2+}$ uncaging. Bottom, Mean amperometric current (left axis, thick traces) and mean amperometric charge (right axis, thin traces). Neither the burst $(\boldsymbol{B})$ nor the sustained $(\boldsymbol{C})$ phases of release were rescued by short-term PICK1 overexpression using the SFV system [KO, $n=22$ cells; WT, $n=24$ cells; K0 + PICK1 (SFV), $n=24$ cells; ${ }^{*} p<0.05,{ }^{* *} p<0.01$, and ${ }^{* * *} p<0.001$; one-way ANOVA with Tukey's post-test $]$. D, Representative images of WT and virally transduced PICK1 $\mathrm{KO}[\mathrm{KO}+\mathrm{PICK} 1(\mathrm{SFV})]$ chromaffin cells immunostained for $\mathrm{GgA}$ and PICK1. Scale bar, $2 \mu \mathrm{m}$. $\boldsymbol{E}$, Quantification of the PICK1 immunofluorescence and $(\boldsymbol{F})$ of the $\mathrm{CgA}$ immunofluorescence (WT, $n=$ 12 cells; K0, $n=12$ cells; ${ }^{*} p<0.05$ and ${ }^{* * *} p<0.001$; Student's $s$ test). Despite high expression of PICK1, no rescue of secretion or CgA content was detected. G-L, Long-term PICK1 re-expression using an LV vector. $\boldsymbol{G}$, Organization and explanation as for $\boldsymbol{A}$. $\boldsymbol{H}$, The burst phase of release was fully rescued whereas $(\boldsymbol{I})$ rescue of the sustained phase did not reach statistical significance, but displayed a strong trend (KO, $n=29$ cells; rescue, $n=30$ cells; ${ }^{\#} p=0.0517$ and ${ }^{* * *} p<0.001$; Student's t test). J, Representative images of PICK1 K0 and virally transduced PICK1 KO [KO + PICK1 (LV)] chromaffin cells immunostained for CgA and PICK1. Scale bar, $2 \mu \mathrm{m}$. $\boldsymbol{K}$, Quantification of the PICK1 immunofluorescence and ( $\boldsymbol{L}$ ) of the CgA immunofluorescence [K0, $n=15$ cells; rescue (KO + PICK1 (LV)], $n=20$ cells; ${ }^{*} p<0.05$ and ${ }^{* * *} p<0.001$; Student'st test). M, Western blot demonstrating expression of PICK1 from SFV and LV constructs in COS-7 cells. A.U., arbitrary units; Fluor. int., fluorescence intensity.

levels of PICK1 expression in EGFP-positive cells to be manyfold higher than in WT cells (Fig. 9D,E,M), but, in accordance with the failure to rescue secretion, the levels of CgA were still reduced in these cells (Fig. 9F). This same SFV expression system has successfully rescued the secretion deficits associated with the loss of proteins that are directly involved in exocytosis, such as SNAP-25 (Sørensen et al., 2003b), synaptobrevin-2 (Kesavan et al., 2007), Snapin (Tian et al., 2005) and synaptotagmin-1 (Nagy et al., 2006). Therefore, this result points to a likely function of PICK1 upstream of exocytosis itself or, alternatively, to a developmental phenotype that cannot be rescued by re-expression of
PICK1. Interestingly, a study using a fluorescent "timer" protein showed that newly generated vesicles equilibrate with the reserve pool of vesicles within $16 \mathrm{~h}$ (Duncan et al., 2003). This could mean that $6 \mathrm{~h}$ of PICK1 re-expression is not enough time for cells to recycle all or most of their LDCVs and replace them with properly generated ones.

We therefore turned to a longer term rescue strategy, using an LV vector expressing PICK1 followed by an IRES and ZsGreen1 as an expression marker. The cells were infected for $48 \mathrm{~h}$ and again tested for secretion by calcium uncaging. As can be seen in Figure $9 G$ (and quantified in $H$ and $I$ ), long-term PICK1 expres- 
sion significantly increased secretion in $\mathrm{KO}$ cells by $\sim 2$-fold. Immunostaining on infected cells revealed that PICK1 was expressed throughout the cell, which contrasts with the restricted localization pattern seen in WT cells (compare Figs. 1, 9J; Fig. 9M demonstrates expression of PICK1 by the LV construct in cultured cells), and indicates that part of the protein was mislocalized. Nevertheless, the rescue of secretion and the increased amounts of CgA by $\sim 2$-fold (Fig. $9 \mathrm{~J}-L$ ) show that expressed PICK1 was functional, implying that part of the protein must be properly localized. The increased amount of CgA is consistent both with the increased secretion seen in infected cells and with the $\sim 2$-fold difference in the amount of CgA found between WT and KO cells (Fig. 8). We conclude that the effect of removing PICK1 is cell autonomous, but reestablishing function requires longterm expression. This is consistent with PICK1 playing an upstream role in vesicle biogenesis and size maturation.

\section{PICK1 lipid interactions are essential} for functional LDCV generation

Using our LV rescue system, we next asked which properties of the PICK1 protein are required for LDCV generation. We focused on two well-characterized mutations, which have previously been shown to eliminate the function of PICK1 in AMPA receptor trafficking. The $2 \mathrm{~K}-\mathrm{E}$ mutation (K266E/K268E) targets two lysines in the BAR domain, which are implicated in lipid interaction. The mutation reduces, but does not eliminate, PICK1 lipid interaction and disrupts synaptic targeting of PICK1 and GluR1/2 receptors, as well as the induction of long-term depression (Jin et al., 2006; Steinberg et al., 2006). The other mutation was the CC-GG substitution (C44G/C46G) within the CPC motif, located close to the PDZ domain. The CPC motif binds directly to membranes, thereby anchoring the PDZ domain, which interacts with various binding partners. The CC-GG mutation reduces lipid interaction of the PDZ domain and eliminates PICK1 clustering and synaptic targeting of PICK1 and GluR1 and GluR2/3 receptors (Pan et al., 2007).

When expressed in the PICK1 KO chromaffin cells using LV transduction, both mutations failed to re-establish release (Fig. $10 A-G)$. Neither mutation resulted in significant changes of either the burst or the sustained-release components (Fig. $10 B, C, E, F)$. Quantitative immunofluorescence demonstrated that both mutations were expressed at similar levels as the WT protein (Fig. $11 A, B$ ). Surprisingly, the $2 \mathrm{~K}-\mathrm{E}$ mutation actually caused a similar increase in overall CgA staining as WT PICK1 (rescue), whereas the CC-GG mutation caused a smaller, but significant, increase in $\mathrm{CgA}$, which did not reach the same level as when expressing PICK1 WT (Fig. 11A,C). Since secretion was
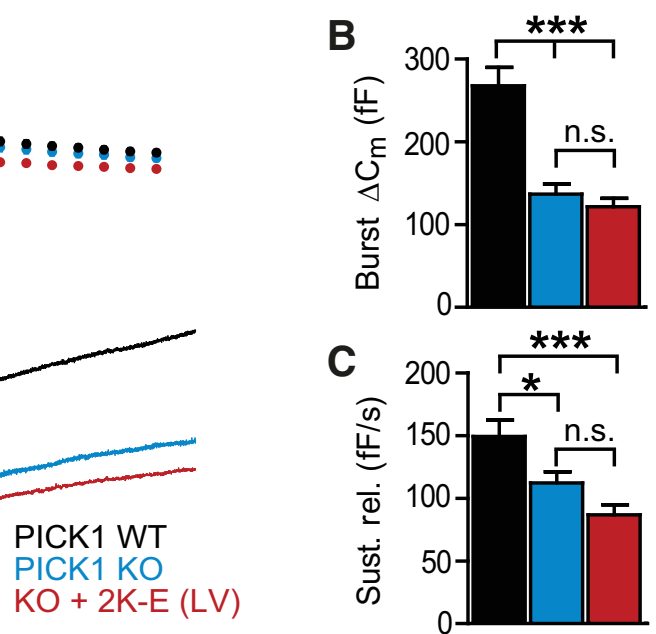

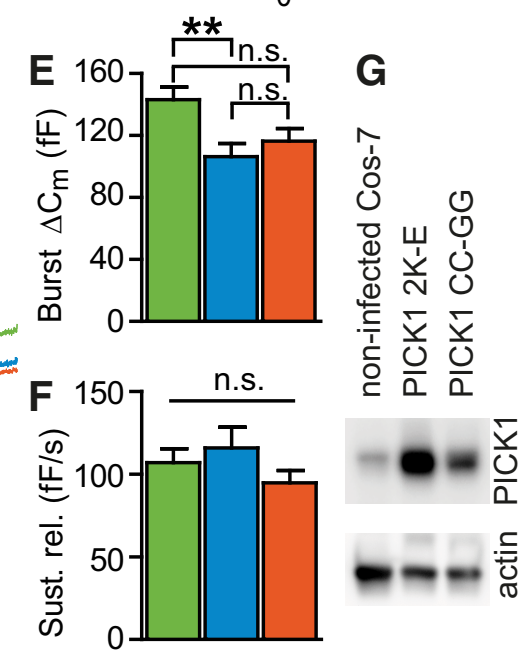

G
PICK1 KO

$\mathrm{KO}+\mathrm{PICK} 1 \mathrm{WT}$

$\mathrm{KO}+\mathrm{CC}-\mathrm{GG}(\mathrm{LV})$

Figure 10. Two mutations that disrupt PICK1 lipid interaction fail to rescue secretion. $\boldsymbol{A}$, Top, Mean \pm SEM intracellular $\left[\mathrm{Ca}^{2+}\right]$ p 0.001; one-way ANOVA with Tukey's post-test). D, Expression of the (C-GG mutation. Top and bottom, Arrange

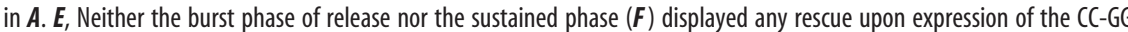
PICK1 K0 cells using an LV vector (PICK1 KO, $n=30$ cells; PICK1 K0 cells expression PICK1 WT, $n=44$ cells; KO cells expressing PICK1 CC-GG, $n=36$ cells; ${ }^{* *} p<0.01$; one-way ANOVA with Tukey's post-test). $\mathbf{G}$, Western blot demonstrating expression of PICK1 2K-E and CC-GG in COS-7 cells.

still depressed upon 2K-E or CC-GG expression, we conclude that the overexpression of these mutations causes the formation of CgA accumulations, which do not represent functional granules.

In conclusion, two PICK1 mutations that disrupt lipid binding and AMPA receptor trafficking also fail to re-establish functional vesicle biogenesis in adrenal chromaffin cells, indicating that a common mechanism of PICK1 function is involved in the two processes.

\section{Discussion}

The biogenesis of secretory vesicles is an essential cellular process that must be strictly regulated to ensure that the formed vesicles are suitable to fulfil their ultimate purpose: the release of their contents upon fusion with the plasma membrane. In the present work we have identified a function for the BAR domain protein PICK1 in the regulation of LDCV biogenesis in chromaffin cells. We found that (1) in the PICK1 KO catecholamine secretion from chromaffin cells is severely impaired, with no change in its 

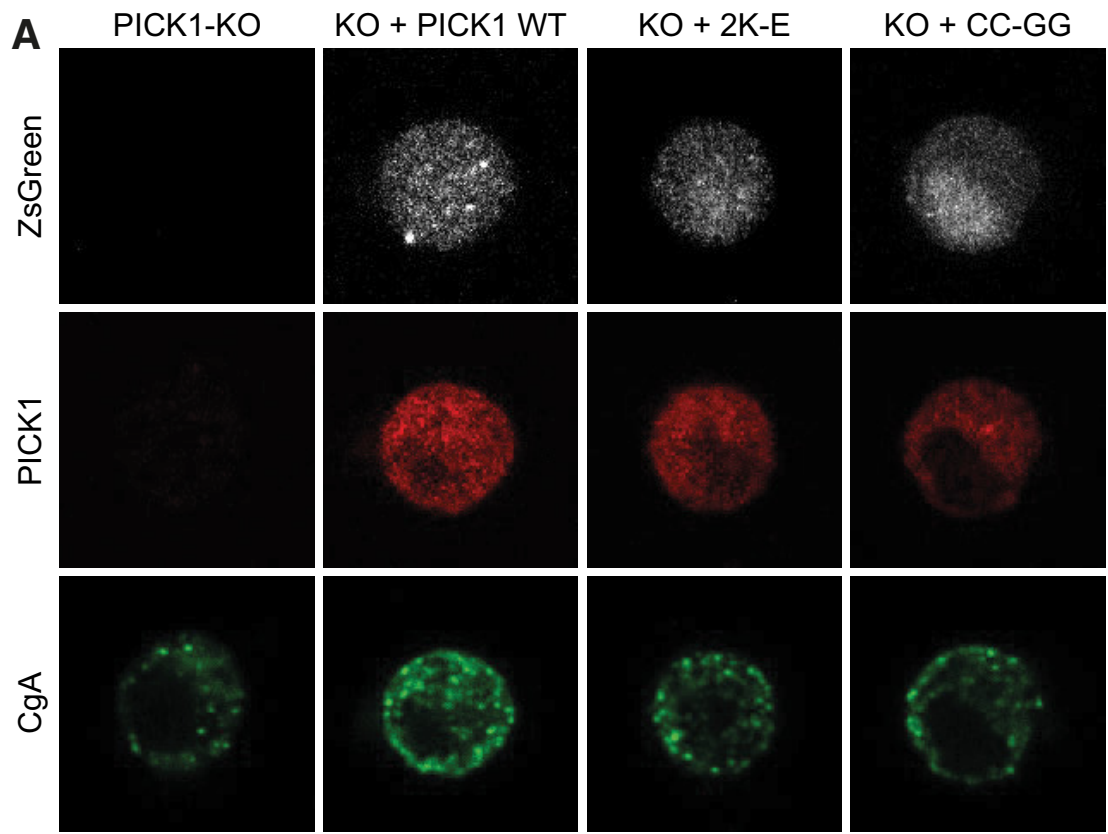
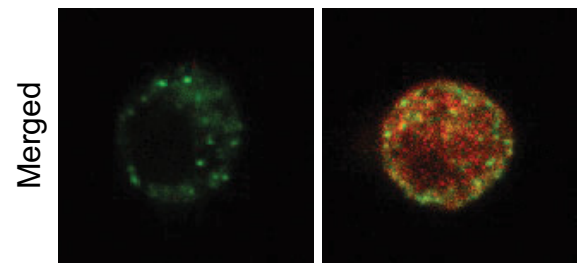

B

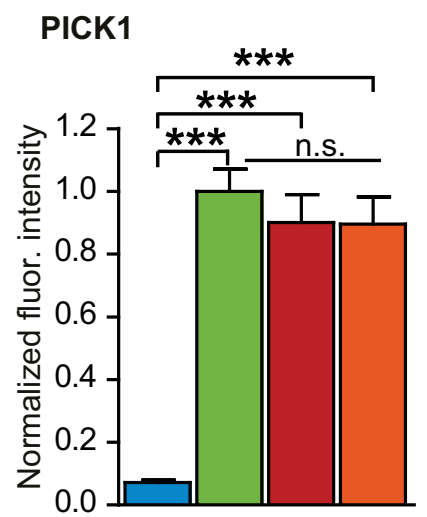

PICK1 KO

$\mathrm{KO}+\mathrm{PICK} 1 \mathrm{WT}$
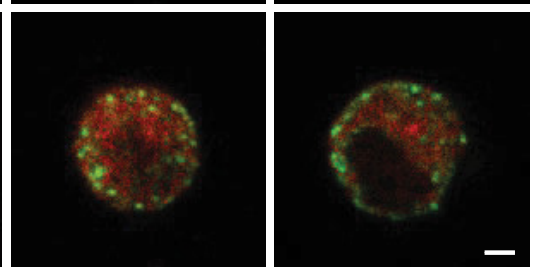

C

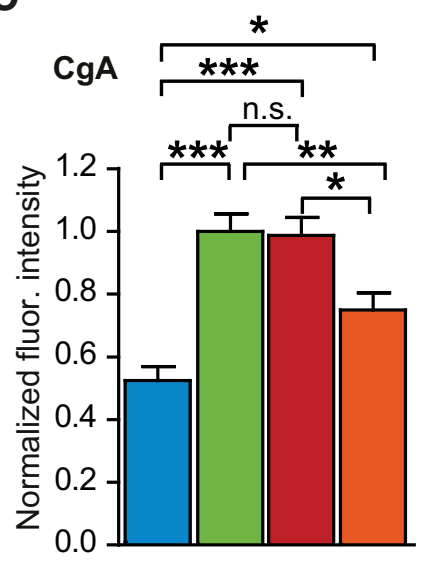

$\mathrm{KO}+\mathrm{PICK} 12 \mathrm{~K}-\mathrm{E}$

KO + PICK1 CC-GG

Figure 11. PICK1 lipid interaction 2K-E mutant rescues chromogranin contents. $A$, Single confocal slices obtained near the equatorial plane of PICK1 K0 chromaffin cells, PICK1 K0 cells expressing PICK1 WT, PICK1 KO cells expressing PICK1 2K-E mutation, and PICK1 KO cells expressing PICK1 CC-GG mutation. Top, ZsGreen 1 fluorescence (expression control); second row, PICK1 immunofluorescence; third row, CgA immunofluorescence; and fourth row, merged images of PICK1 and CgA channel. Scale bar, $2 \mu \mathrm{m}$. $B$, Quantification of PICK1 immunofluorescence demonstrates similar expression levels in the three expressing groups. C, Quantification of $\mathrm{C} g \mathrm{~A}$ immunofluorescence showed that PICK1 WT and PICK1 2 K-E mutation both rescue the lower levels of $\mathrm{G} \mathrm{g}$ observed in PICK1 KO cells, whereas PICK1 CC-GG displayed an intermediate effect. (PICK1 K0, $n=60$ cells; PICK1 K0 cells expressing PICK1 WT, $n=66$ cells; K0 cells expressing PICK1 2-KE, $n=49$ cells; K0 cells expressing PICK1 CC-GG, $n=48$ cells; ${ }^{*} p<0.05$, ${ }^{* *} p<$ 0.01 , and ${ }^{* * *} p<0.001$; one-way ANOVA with Tukey's post-test).

release kinetics or calcium dependence; (2) single-vesicle fusion events are fewer, release smaller amounts of catecholamines, and contribute smaller increases to the membrane capacitance; (3) LDCVs are smaller and fewer, with a corresponding decrease in the overall level of CgA in the cell; (4) long-term re-expression of PICK1 is required to rescue normal levels of CgA and of catechol- amine secretion; and (5) lipid binding of both the BAR and PDZ domains is essential for the function of PICK1 in vesicle generation. Thus, our data clearly indicate that the main defect in PICK1 KO cells is the reduced or aberrant biogenesis of secretory granules, leading to impaired secretion.

One could envision two scenarios where the absence of PICK1 would influence membrane fusion. One would be indirectly, by creating vesicles with altered composition during biogenesis, or by halting maturation of immature vesicles, which could lead to downstream defects in fusion. The other would be directly, by interference with the fusion machinery itself. The latter mechanism would require PICK1 to be localized to either mature vesicles or the plasma membrane, which we did not find evidence for in chromaffin cells. The predominant localization to a syntaxin-6-positive compartment in chromaffin cells agrees with studies in human growth hormone-producing cells (Holst et al., 2013). In $\beta$-cells, PICK1 (with ICA69) was found partly localized to immature vesicles, and partly (without ICA69) to mature, dense core vesicles (Cao et al., 2013). Nevertheless, the ratio of secreted insulin to total cellular insulin was unchanged after deletion of PICK1, leading the authors to conclude that the exocytosis machinery is most likely not defective in the absence of PICK1 (Cao et al., 2013), even though cellular release assays were not performed. In contrast, a recent study of Arfaptin-1, a BAR domain protein closely related to PICK1, identified smaller insulin granules, impaired docking of granules, and reduced insulin secretion upon depletion of Arfaptin-1 and attributed these findings to the generation of nonfunctional insulin granules, which would be subsequently degraded (Gehart et al., 2012).

By using calcium uncaging to measure the fusion rates of primed vesicles, calcium ramps to detect the secretion threshold, and by analyzing single-vesicle fusion events in detail, we find no evidence that PICK1 participates in the fusion process itself. Thus, the smaller LDCVs generated in the absence of PICK1 retain fusogenicity, implying that PICK1 controls vesicle formation and size, but not the fusion reaction itself. Different stimulation protocols resulted in somewhat different estimates of the reduction in fusion capacity in PICK1 KO cells. Upon depolarization, the size of the IRP was reduced by $\sim 30 \%$, whereas the overall reduction in $\mathrm{Ca}^{2+}$-uncaging experiments was by $\sim 40 \%$ (Fig. 2 ). These reductions are less than expected from the combined decrease in 
overall vesicular content (reduction by $40 \%$ ) and vesicular size (expected decrease in single-vesicle capacitance by $\sim 31 \%$, estimated by EM), yielding an overall expected reduction of $\sim 59 \%$. Therefore, either the smaller vesicles in the PICK1 KO are more fusogenic than in the WT, or-which is probably more likelysome other mechanism regulates the number of vesicles fused. One such mechanism could be the association of vesicles to a priming receptor/machinery. This receptor would include priming proteins such as CAPS (Liu et al., 2010), and-if present in limiting amounts-it might act to keep the number of primed vesicles constant in the face of a reduced vesicle availability.

Recent studies have demonstrated the participation of BAR domain proteins, including PICK1, in vesicle biogenesis. Both PICK1 and ICA69 were found to regulate the formation of insulin- and growth hormone-containing granules; in their absence there is a reduction in the amount of released hormones (Cao et al., 2013; Holst et al., 2013), which correlates with either the presence of more immature granules (Cao et al., 2007) or with a marked reduction in their number (Holst et al., 2013). However, no significant changes in vesicle size were reported by other studies on PICK1 function suggesting that its function in controlling the size of secretory granules might depend on the specific cellular context.

Another interesting finding in our study was that, in order to rescue normal levels of secretion in PICK1 KO chromaffin cells, long re-expression $(48 \mathrm{~h})$ with a lentivirus was required, whereas $6-8 \mathrm{~h}$ strong expression using Semliki virus was ineffective. We have recently published similar findings upon deletion of the SNARE protein vtila, where vesicles were also reduced in number and size, and long-term expression was necessary for rescue (Walter et al., 2014). However, rescue of KOs for integral vesicular proteins (synaptobrevin-2/VAMP-2 and synaptotagmin-1) is complete within $6-8 \mathrm{~h}$ using Semliki viruses (Borisovska et al., 2005; Nagy et al., 2006). We therefore suggested that vtila might participate in an upstream reaction near the TGN, which leads to the formation of premature vesicles that later incorporate membrane proteins necessary for exocytosis. Strikingly, vtila has a similar distribution as PICK1 and also partly overlaps with that of syntaxin-6 (Walter et al., 2014). Thus, a syntaxin-6-positive compartment near the TGN (Kuliawat et al., 2004) — probably related to the compartment necessary for GLUT4 recycling (Shewan et al., 2003) — might be involved in forming vesicles of the correct number and size. While depletion of PICK1 or vtila leads to reduction in vesicle size and number, fully functional vesicles are generated. Thus, both vtila and PICK1 might be nonessential modulators of vesicle biogenesis or there is some degree of redundancy, which can partially compensate for their losses. Nevertheless, our finding that expression of the 2K-E PICK1 mutation rescues the CgA content, but not secretion, indicates that upon mutation of PICK1 nonfunctional vesicles can be formed.

Arfaptin-1 was shown to interact with small GTPases (ARF and Rac1; Kanoh et al., 1997; Shin and Exton, 2001) of the Ras superfamily. Interestingly, the monomeric G-proteins Rab3 (Rab3A-D) are necessary to maintain normal vesicle numbers in mouse chromaffin cells, indicating that they are involved in vesicle biogenesis (Schonn et al., 2010). However, secretion was restored by short-term overexpression of Rab3A, even though the vesicle number was not, indicating that Rab3 proteins play an additional downstream promoting role in vesicle priming (Schonn et al., 2010). Future experiments will reveal whether Rab3 and PICK1 might interact to stimulate vesicle biogenesis.
How, then, would PICK1 participate in the biogenesis of LDCVs? The PICK1 BAR domain possesses membrane-sculpting properties, at least in vitro, and thus has the principal capacity to directly facilitate the budding process (Holst et al., 2013). In addition, PICK1 might participate in the formation of protein scaffolds that would shield the vesicle neck and prevent premature fission, as proposed for Arfaptin-1 (Gehart et al., 2012). The combination of those two mechanisms would cause formation of fewer vesicles (due to impaired budding) of smaller size (due to premature fission) in the absence of PICK1, in agreement with our findings. In support of a role for PICK1 lipid interaction during vesicle biogenesis, we found that two mutations, the $2 \mathrm{~K}-\mathrm{E}$ and the CC-GG, which reduce lipid binding of the BAR domain and the PDZ domain, respectively, both eliminated functional rescue of the PICK1 KO. Both mutations also eliminate synaptic targeting of PICK1 and glutamate receptors (Jin et al., 2006; Steinberg et al., 2006; Pan et al., 2007). Thus, it appears that PICK1 relies on the same basic properties, which at least involve membrane interaction, during the trafficking of AMPA receptors and the generation of secretory vesicles.

The absence of granins also leads to defects in the number of LDCVs and, importantly, to larger sized vesicles (Kim et al., 2001, 2005; Courel et al., 2010; Díaz-Vera et al., 2012). The latter finding could imply some functional interplay between the two classes of proteins. Granins function as the core around which budding from the TGN is initiated (Kim et al., 2006). However, when left to its own devices, this might lead to the formation of smaller vesicles, whereas PICK1 (or other BAR proteins) could stabilize the nascent vesicle from the outside as a scaffolding or proofreading mechanism to ensure a larger size. This would agree with the opposing effects on vesicle size when deleting $\mathrm{CgA}$ (Kim et al., 2005) and PICK1 (this study). However, this mechanism probably cannot explain why deletion of a SNARE protein, vtila, results in a similar reduction in vesicle size (Walter et al., 2014). It is likely that the putative syntaxin-6-positive subcompartment at or near the TGN plays a more complex role, which has yet to be described, in the generation of proper-sized and functional secretory vesicles.

\section{References}

Bhatia VK, Hatzakis NS, Stamou D (2010) A unifying mechanism accounts for sensing of membrane curvature by BAR domains, amphipathic helices and membrane-anchored proteins. Semin Cell Dev Biol 21:381-390. CrossRef Medline

Borgonovo B, Ouwendijk J, Solimena M (2006) Biogenesis of secretory granules. Curr Opin Cell Biol 18:365-370. CrossRef Medline

Borisovska M, Zhao Y, Tsytsyura Y, Glyvuk N, Takamori S, Matti U, Rettig J, Südhof T, Bruns D (2005) v-SNAREs control exocytosis of vesicles from priming to fusion. EMBO J 24:2114-2126. CrossRef Medline

Bruns D (2004) Detection of transmitter release with carbon fiber electrodes. Methods 33:312-321. CrossRef Medline

Burgoyne RD, Morgan A (2003) Secretory granule exocytosis. Physiol Rev 83:581-632. Medline

Cao M, Xu J, Shen C, Kam C, Huganir RL, Xia J (2007) PICK1-ICA69 heteromeric BAR domain complex regulates synaptic targeting and surface expression of AMPA receptors. J Neurosci 27:12945-12956. CrossRef Medline

Cao M, Mao Z, Kam C, Xiao N, Cao X, Shen C, Cheng KK, Xu A, Lee KM, Jiang L, Xia J (2013) PICK1 and ICA69 control insulin granule trafficking and their deficiencies lead to impaired glucose tolerance. PLoS Biol 11:e1001541. CrossRef Medline

Chow RH, von Rüden L, Neher E (1992) Delay in vesicle fusion revealed by electrochemical monitoring of single secretory events in adrenal chromaffin cells. Nature 356:60-63. CrossRef Medline

Citri A, Bhattacharyya S, Ma C, Morishita W, Fang S, Rizo J, Malenka RC (2010) Calcium binding to PICK1 is essential for the intracellular reten- 
tion of AMPA receptors underlying long-term depression. J Neurosci 30:16437-16452. CrossRef Medline

Courel M, Soler-Jover A, Rodriguez-Flores JL, Mahata SK, Elias S, MonteroHadjadje M, Anouar Y, Giuly RJ, O'Connor DT, Taupenot L (2010) Pro-hormone secretogranin II regulates dense core secretory granule biogenesis in catecholaminergic cells. J Biol Chem 285:10030-10043. CrossRef Medline

Díaz-Vera J, Camacho M, Machado JD, Domínguez N, Montesinos MS, Hernández-Fernaud JR, Luján R, Borges R (2012) Chromogranins A and $\mathrm{B}$ are key proteins in amine accumulation, but the catecholamine secretory pathway is conserved without them. FASEB J 26:430-438. CrossRef Medline

Duncan RR, Greaves J, Wiegand UK, Matskevich I, Bodammer G, Apps DK, Shipston MJ, Chow RH (2003) Functional and spatial segregation of secretory vesicle pools according to vesicle age. Nature 422:176-180. CrossRef Medline

Frost A, Unger VM, De Camilli P (2009) The BAR domain superfamily: membrane-molding macromolecules. Cell 137:191-196. CrossRef Medline

Fulop T, Radabaugh S, Smith C (2005) Activity-dependent differential transmitter release in mouse adrenal chromaffin cells. J Neurosci 25: 7324-7332. CrossRef Medline

Gardner SM, Takamiya K, Xia J, Suh JG, Johnson R, Yu S, Huganir RL (2005) Calcium-permeable AMPA receptor plasticity is mediated by subunitspecific interactions with PICK1 and NSF. Neuron 45:903-915. CrossRef Medline

Gehart H, Goginashvili A, Beck R, Morvan J, Erbs E, Formentini I, De Matteis MA, Schwab Y, Wieland FT, Ricci R (2012) The BAR domain protein Arfaptin-1 controls secretory granule biogenesis at the trans-Golgi network. Dev Cell 23:756-768. CrossRef Medline

Habermann B (2004) The BAR-domain family of proteins: a case of bending and binding? EMBO Rep 5:250-255. CrossRef Medline

Hanley JG (2008) PICK1: a multi-talented modulator of AMPA receptor trafficking. Pharmacol Ther 118:152-160. CrossRef Medline

Hanley JG, Henley JM (2005) PICK1 is a calcium-sensor for NMDAinduced AMPA receptor trafficking. EMBO J 24:3266-3278. CrossRef Medline

Hannemann M, Sasidharan N, Hegermann J, Kutscher LM, Koenig S, Eimer S (2012) TBC-8, a putative RAB-2 GAP, regulates dense core vesicle maturation in Caenorhabditis elegans. PLoS Genet 8:e1002722. CrossRef Medline

Holst B, Madsen KL, Jansen AM, Jin C, Rickhag M, Lund VK, Jensen M, Bhatia V, Sørensen G, Madsen AN, Xue Z, Møller SK, Woldbye D, Qvortrup K, Huganir R, Stamou D, Kjaerulff O, Gether U (2013) PICK1 Deficiency impairs secretory vesicle biogenesis and leads to growth retardation and decreased glucose tolerance. PLoS Biol 11:e1001542. CrossRef Medline

Horrigan FT, Bookman RJ (1994) Releasable pools and the kinetics of exocytosis in adrenal chromaffin cells. Neuron 13:1119-1129. CrossRef Medline

Jackson MB, Chapman ER (2008) The fusion pores of Ca2+-triggered exocytosis. Nat Struct Mol Biol 15:684-689. CrossRef Medline

Jin W, Ge WP, Xu J, Cao M, Peng L, Yung W, Liao D, Duan S, Zhang M, Xia J (2006) Lipid binding regulates synaptic targeting of PICK1, AMPA receptor trafficking, and synaptic plasticity. J Neurosci 26:2380-2390. CrossRef Medline

Jo J, Heon S, Kim MJ, Son GH, Park Y, Henley JM, Weiss JL, Sheng M, Collingridge GL, Cho K (2008) Metabotropic glutamate receptormediated LTD involves two interacting $\mathrm{Ca}(2+)$ sensors, NCS-1 and PICK1. Neuron 60:1095-1111. CrossRef Medline

Kanoh H, Williger BT, Exton JH (1997) Arfaptin 1, a putative cytosolic target protein of ADP-ribosylation factor, is recruited to Golgi membranes. J Biol Chem 272:5421-5429. CrossRef Medline

Kasai H, Takahashi N, Tokumaru H (2012) Distinct initial SNARE configurations underlying the diversity of exocytosis. Physiol Rev 92:19151964. CrossRef Medline

Kesavan J, Borisovska M, Bruns D (2007) v-SNARE actions during Ca(2+)triggered exocytosis. Cell 131:351-363. CrossRef Medline

Kim T, Tao-Cheng JH, Eiden LE, Loh YP (2001) Chromogranin A, an "on/ off" switch controlling dense-core secretory granule biogenesis. Cell 106: 499-509. CrossRef Medline

Kim T, Zhang CF, Sun Z, Wu H, Loh YP (2005) Chromogranin A deficiency in transgenic mice leads to aberrant chromaffin granule biogenesis. J Neurosci 25:6958-6961. CrossRef Medline

Kim T, Gondré-Lewis MC, Arnaoutova I, Loh YP (2006) Dense-core secretory granule biogenesis. Physiology 21:124-133. CrossRef Medline

Kirchhausen T (2000) Three ways to make a vesicle. Nat Rev Mol Cell Biol 1:187-198. CrossRef Medline

Klumperman J, Kuliawat R, Griffith JM, Geuze HJ, Arvan P (1998) Mannose 6-phosphate receptors are sorted from immature secretory granules via adaptor protein AP-1, clathrin, and syntaxin 6-positive vesicles. J Cell Biol 141:359-371. CrossRef Medline

Kuliawat R, Kalinina E, Bock J, Fricker L, McGraw TE, Kim SR, Zhong J, Scheller R, Arvan P (2004) Syntaxin-6 SNARE involvement in secretory and endocytic pathways of cultured pancreatic beta-cells. Mol Biol Cell 15:1690-1701. CrossRef Medline

Lipovšek S, Janžekovič F, Leitinger G, Rupnik MS (2013) Rab3a ablation related changes in morphology of secretory vesicles in major endocrine pancreatic cells, pituitary melanotroph cells and adrenal gland chromaffin cells in mice. Gen Comp Endocrinol 185:67-79. CrossRef Medline

Liu Y, Schirra C, Edelmann L, Matti U, Rhee J, Hof D, Bruns D, Brose N, Rieger H, Stevens DR, Rettig J (2010) Two distinct secretory vesiclepriming steps in adrenal chromaffin cells. J Cell Biol 190:1067-1077. CrossRef Medline

Lu W, Ziff EB (2005) PICK1 interacts with ABP/GRIP to regulate AMPA receptor trafficking. Neuron 47:407-421. CrossRef Medline

Madsen KL, Bhatia VK, Gether U, Stamou D (2010) BAR domains, amphipathic helices and membrane-anchored proteins use the same mechanism to sense membrane curvature. FEBS Lett 584:1848-1855. CrossRef Medline

McMahon HT, Boucrot E (2011) Molecular mechanism and physiological functions of clathrin-mediated endocytosis. Nat Rev Mol Cell Biol 12: 517-533. CrossRef Medline

Mohrmann R, de Wit H, Connell E, Pinheiro PS, Leese C, Bruns D, Davletov B, Verhage M, Sørensen JB (2013) Synaptotagmin Interaction with SNAP-25 Governs Vesicle Docking, Priming, and Fusion Triggering. J Neurosci 33:14417-14430. CrossRef Medline

Moser T, Neher E (1997) Estimation of mean exocytic vesicle capacitance in mouse adrenal chromaffin cells. Proc Natl Acad Sci U S A 94:6735-6740. CrossRef Medline

Mosharov EV (2008) Analysis of single-vesicle exocytotic events recorded by amperometry. Methods Mol Biol 440:315-327. CrossRef Medline

Mosharov EV, Sulzer D (2005) Analysis of exocytotic events recorded by amperometry. Nat Methods 2:651-658. CrossRef Medline

Nagy G, Kim JH, Pang ZP, Matti U, Rettig J, Südhof TC, SørensenJB (2006) Different effects on fast exocytosis induced by synaptotagmin 1 and 2 isoforms and abundance but not by phosphorylation. J Neurosci 26:632643. CrossRef Medline

Pan L, Wu H, Shen C, Shi Y, Jin W, Xia J, Zhang M (2007) Clustering and synaptic targeting of PICK1 requires direct interaction between the PDZ domain and lipid membranes. EMBO J 26:4576-4587. CrossRef Medline

Peter BJ, Kent HM, Mills IG, Vallis Y, Butler PJ, Evans PR, McMahon HT (2004) BAR domains as sensors of membrane curvature: the amphiphysin BAR structure. Science 303:495-499. CrossRef Medline

Pietropaolo M, Castaño L, Babu S, Buelow R, Kuo YL, Martin S, Martin A, Powers AC, Prochazka M, Naggert J, et al. (1993) Islet cell autoantigen $69 \mathrm{kD}$ (ICA69). Molecular cloning and characterization of a novel diabetes-associated autoantigen. J Clin Invest 92:359-371. CrossRef Medline

Pinheiro PS, de Wit H, Walter AM, Groffen AJ, Verhage M, Sørensen JB (2013) Doc2b synchronizes secretion from chromaffin cells by stimulating fast and inhibiting sustained release. J Neurosci 33:16459-16470. CrossRef Medline

Rao Y, Haucke V (2011) Membrane shaping by the Bin/amphiphysin/Rvs (BAR) domain protein superfamily. Cell Mol Life Sci 68:3983-3993. CrossRef Medline

Rettig J, Neher E (2002) Emerging roles of presynaptic proteins in $\mathrm{Ca}++$ triggered exocytosis. Science 298:781-785. CrossRef Medline

Saheki Y, De Camilli P (2012) Synaptic vesicle endocytosis. Cold Spring Harb Perspect Biol 4:a005645. CrossRef Medline

Schonn JS, van Weering JR, Mohrmann R, Schlüter OM, Sñdhof TC, de Wit H, Verhage M, Sørensen JB (2010) Rab3 proteins involved in vesicle biogenesis and priming in embryonic mouse chromaffin cells. Traffic 11:1415-1428. CrossRef Medline 
Shewan AM, van Dam EM, Martin S, Luen TB, Hong W, Bryant NJ, James DE (2003) GLUT4 recycles via a trans-Golgi network (TGN) subdomain enriched in Syntaxins 6 and 16 but not TGN38: involvement of an acidic targeting motif. Mol Biol Cell 14:973-986. CrossRef Medline

Shin OH, Exton JH (2001) Differential binding of arfaptin 2/POR1 to ADPribosylation factors and Rac1. Biochem Biophys Res Commun 285:12671273. CrossRef Medline

Sørensen JB, MattiU, WeiSH, Nehring RB, Voets T, Ashery U, Binz T, Neher E, Rettig J (2002) The SNARE protein SNAP-25 is linked to fast calcium triggering of exocytosis. Proc Natl Acad Sci U S A 99:1627-1632. CrossRef Medline

Sørensen JB, Fernández-Chacón R, Südhof TC, Neher E (2003a) Examining synaptotagmin 1 function in dense core vesicle exocytosis under direct control of $\mathrm{Ca}^{2+}$. J Gen Physiol 122:265-276. CrossRef Medline

Sørensen JB, Nagy G, Varoqueaux F, Nehring RB, Brose N, Wilson MC, Neher E (2003b) Differential control of the releasable vesicle pools by SNAP-25 splice variants and SNAP-23. Cell 114:75-86. CrossRef Medline

Spang A (2008) The life cycle of a transport vesicle. Cell Mol Life Sci 65: 2781-2789. CrossRef Medline

Staudinger J, Zhou J, Burgess R, Elledge SJ, Olson EN (1995) PICK1: a perinuclear binding protein and substrate for protein kinase $\mathrm{C}$ isolated by the yeast two-hybrid system. J Cell Biol 128:263-271. CrossRef Medline

Steinberg JP, Takamiya K, Shen Y, Xia J, Rubio ME, Yu S, Jin W, Thomas GM, Linden DJ, Huganir RL (2006) Targeted in vivo mutations of the AMPA receptor subunit GluR2 and its interacting protein PICK1 eliminate cerebellar long-term depression. Neuron 49:845-860. CrossRef Medline

Suetsugu S, Toyooka K, Senju Y (2010) Subcellular membrane curvature mediated by the BAR domain superfamily proteins. Semin Cell Dev Biol 21:340-349. CrossRef Medline

Sumakovic M, Hegermann J, Luo L, Husson SJ, Schwarze K, Olendrowitz C, Schoofs L, Richmond J, Eimer S (2009) UNC-108/RAB-2 and its effector RIC-19 are involved in dense core vesicle maturation in Caenorhabditis elegans. J Cell Biol 186:897-914. CrossRef Medline

Tabares L, Alés E, Lindau M, Alvarez de Toledo G (2001) Exocytosis of catecholamine (CA)-containing and CA-free granules in chromaffin cells. J Biol Chem 276:39974-39979. CrossRef Medline
Thorsen TS, Madsen KL, Rebola N, Rathje M, Anggono V, Bach A, Moreira IS, Stuhr-Hansen N, Dyhring T, Peters D, Beuming T, Huganir R, Weinstein H, Mulle C, Strømgaard K, Rønn LC, Gether U (2010) Identification of a small-molecule inhibitor of the PICK1 PDZ domain that inhibits hippocampal LTP and LTD. Proc Natl Acad Sci U S A 107:413-418. CrossRef Medline

Tian JH, Wu ZX, Unzicker M, Lu L, Cai Q, Li C, Schirra C, Matti U, Stevens D, Deng C, Rettig J, Sheng ZH (2005) The role of Snapin in neurosecretion: snapin knock-out mice exhibit impaired calciumdependent exocytosis of large dense-core vesicles in chromaffin cells. J Neurosci 25:10546-10555. CrossRef Medline

Toonen RF, Kochubey O, de Wit H, Gulyas-Kovacs A, Konijnenburg B, Sørensen JB, Klingauf J, Verhage M (2006) Dissecting docking and tethering of secretory vesicles at the target membrane. EMBO J 25:3725-3737. CrossRef Medline

Tooze SA, Martens GJ, Huttner WB (2001) Secretory granule biogenesis: rafting to the SNARE. Trends Cell Biol 11:116-122. CrossRef Medline

Voets T (2000) Dissection of three Ca2+-dependent steps leading to secretion in chromaffin cells from mouse adrenal slices. Neuron 28:537-545. CrossRef Medline

Voets T, Neher E, Moser T (1999) Mechanisms underlying phasic and sustained secretion in chromaffin cells from mouse adrenal slices. Neuron 23:607-615. CrossRef Medline

Walter AM, Pinheiro PS, Verhage M, Sørensen JB (2013) A sequential vesicle pool model with a single release sensor and a $\mathrm{Ca}(2+)$-dependent priming catalyst effectively explains $\mathrm{ca}(2+)$-dependent properties of neurosecretion. PLoS Comput Biol 9:e1003362. CrossRef Medline

Walter AM, Kurps J, de Wit H, Schoning S, Toft-Bertelsen TL, Lauks J, Ziomkiewicz I, Weiss AN, Schulz A, Fischer von Mollard G, Verhage M, Sorensen JB (2014) The SNARE protein vtila functions in dense-core vesicle biogenesis. EMBO J pii:e201387549. Medline

Wendler F, Page L, Urbé S, Tooze SA (2001) Homotypic fusion of immature secretory granules during maturation requires syntaxin $6 . \mathrm{Mol}$ Biol Cell 12:1699-1709. CrossRef Medline 